\title{
Biological and Psychological Factors Determining Neuropsychiatric Outcomes in COVID-19
}

\author{
Boris N. Tizenberg ${ }^{1} \cdot$ Lisa A. Brenner 2,3,4,5 . Christopher A. Lowry 2,3,5,6,7,8 . Olaoluwa O. Okusaga ${ }^{9,10}$. \\ David R. Benavides ${ }^{11}$. Andrew J. Hoisington ${ }^{2,3,5,12} \cdot$ Michael E. Benros $^{13,14} \cdot$ John W. Stiller ${ }^{1,15,16} \cdot$ Ronald C. Kessler $^{17}$. \\ Teodor T. Postolache ${ }^{1,2,5,18}$ (1)
}

Accepted: 6 July 2021 / Published online: 1 October 2021

This is a U.S. government work and not under copyright protection in the U.S.; foreign copyright protection may apply 2021

\begin{abstract}
Purpose of Review We present biological and psychological factors implicated in psychiatric manifestations of SARS-CoV-2, as well as its neuroinvasive capability and immune pathophysiology.

Recent Findings Preexisting mental illness leads to worse clinical outcomes in COVID-19. The presence of the virus was reported in the cerebrospinal fluid (CSF) and brain tissue post-mortem. Most common psychiatric manifestations include delirium, mood disorders, anxiety disorders, and posttraumatic stress disorder. "Long-COVID" non-syndromal presentations include "brain-fogginess," autonomic instability, fatigue, and insomnia.

Summary SARS-CoV-2 infection can trigger prior vulnerabilities based on the priming of microglia and other cells, induced or perpetuated by aging and mental and physical illnesses. COVID-19 could further induce priming of neuroimmunological substrates leading to exacerbated immune response and autoimmunity targeting structures in the central nervous system (CNS), in response to minor immune activating environmental exposures, including stress, minor infections, allergens, pollutants, and traumatic brain injury.
\end{abstract}

Keywords COVID-19 $\cdot$ SARS-CoV-2 $\cdot$ Neuroinflammation $\cdot$ Neuroinvasion $\cdot$ Neuropsychiatric $\cdot$ Priming

\begin{tabular}{|c|c|c|c|}
\hline \multicolumn{2}{|c|}{ Abbreviations } & $\mathrm{CD}$ & Cluster of differentiation \\
\hline \multirow{5}{*}{$\begin{array}{l}\text { ACE2 } \\
\text { ACEI } \\
\text { ADEM } \\
\text { AHLE }\end{array}$} & Angiotensin I-converting enzyme 2 & $\mathrm{CDC}$ & Center for Disease Control and Prevention \\
\hline & Angiotensin-converting enzyme inhibitor & CCL2 & $\mathrm{C}-\mathrm{C}$ motif chemokine ligand 2 , also \\
\hline & Acute disseminated encephalomyelitis & & known as monocyte chemotactic protein \\
\hline & Acute hemorrhagic & & $(\mathrm{MCP})-1$ \\
\hline & leukoencephalomyelitis & CEC & Circulating endothelial cells \\
\hline \multirow{4}{*}{$\begin{array}{l}\text { ANA } \\
\text { ANE } \\
\text { anti-dsDNA }\end{array}$} & Antinuclear antibodies & CNS & Central nervous system \\
\hline & Acute necrotizing encephalopathy & CORONADO & Coronavirus-SARS-CoV-2 and diabetes \\
\hline & Anti-double-stranded deoxyribonucleic & & outcomes \\
\hline & acid & COVID-19 & Coronavirus disease 2019 \\
\hline ARBs & Angiotensin receptor blockers & $\mathrm{CoVs}$ & Coronaviruses \\
\hline AST & Aspartate aminotransferase & $\mathrm{Cr}$ & Creatinine \\
\hline $\mathrm{BBB}$ & Blood-brain barrier & CRP & C-reactive protein \\
\hline BMI & Body mass index & CSF & Cerebrospinal fluid \\
\hline \multirow[t]{3}{*}{$\mathrm{CBT}$} & Cognitive behavioral therapy & CT & Computed tomography \\
\hline & & CTSL & Cathepsin L \\
\hline & & CVD & Cardiovascular disease \\
\hline \multicolumn{2}{|c|}{$\begin{array}{l}\text { This article is part of the Topical Collection on Complex Medical- } \\
\text { Psychiatric Issues. }\end{array}$} & DCLO & $\begin{array}{l}\text { Diffusing capacity of the lungs for carbon } \\
\text { monoxide }\end{array}$ \\
\hline \multirow{2}{*}{\multicolumn{2}{|c|}{$\begin{array}{l}\square \text { Teodor T. Postolache } \\
\text { tpostola@ som.umaryland.edu }\end{array}$}} & DSM-IV & $\begin{array}{l}\text { Diagnostic and Statistical Manual of } \\
\text { Mental Disorders, fourth edition }\end{array}$ \\
\hline & & EEG & Electroencephalogram \\
\hline
\end{tabular}




$\begin{array}{llll}\text { E protein } & \text { Envelope protein } & \text { SLE } & \text { Systemic lupus erythematosus } \\ \text { ED } & \text { Emergency department } & \text { sVCAM-1 } & \text { Soluble vascular cell adhesion molecule-1 } \\ \text { Fab } & \text { Antigen-binding fragment } & \text { TBI } & \text { Traumatic brain injury } \\ \text { Fc } & \text { Fragment crystallizable } & \text { Th1 } & \text { T helper cell type 1 } \\ \text { FDP } & \text { Fibrin/fibrinogen degradation products } & \text { Th2 } & \text { T helper cell type 2 } \\ \text { FIB } & \text { Fibrinogen } & \text { Th17 } & \text { T helper cell type 17 } \\ \text { GI } & \text { Gastrointestinal } & \text { TIM-3 } & \text { Hepatitis A virus cellular receptor 2 } \\ \text { HCoV } & \text { Human coronavirus } & \text { TBI } & \text { Traumatic brain injury } \\ \text { IBD } & \text { Inflammatory bowel disease } & \text { TGF } \beta 1 & \text { Transforming growth factor beta 1 } \\ \text { ICU } & \text { Intensive care unit } & \text { TLR } & \text { Toll-like receptor } \\ \text { IFN } \alpha & \text { Interferon alpha } & \text { TNF } \alpha & \text { Tumor necrosis factor alpha } \\ \text { IFN } \beta & \text { Interferon beta } & \text { TMPRSS2 } & \text { Transmembrane protease serine 2 } \\ \text { IFN } \gamma & \text { Interferon gamma } & \text { TSPO } & \text { Mitochondrial translocator protein } \\ \text { IL } & \text { Interleukin } & \text { US } & \text { United States }\end{array}$

\section{Introduction}

In 2019, a new virus, severe acute respiratory syndrome coronavirus 2 (SARS-CoV-2), spread across the world and caused what has become known as coronavirus disease 2019 (COVID-19), a systemic illness with heterogeneous presentation and potential for pan-organ involvement. The COVID-19 pandemic has led to unprecedented widespread and intertwined psychological and social stress secondary to people fearing for their lives and those of their loved ones, economic distress, isolation, loneliness, tensions associated with racism and xenophobia (especially towards people of East Asian descent), as well as disparities in healthcare. Results from the Household Pulse Survey, implemented by the National Center for Health Statistics (NCHS) and the Census Bureau to monitor the impact of the pandemic, suggest substantial increases of both anxiety and depressive symptoms among US residents [1]. Moreover, rates of infection and severity of illness are higher in individuals with a preexisting diagnosis of mental illness [2]. For example, individuals with preexisting schizophrenia spectrum disorders have especially high odds of mortality from SARS-CoV-2, even after adjusting for demographic and medical risk factors. Indeed, in a general population risk factor model, a diagnosis of schizophrenia is second only to age in strength of association with mortality [3].

In this review, we emphasize the intersection between biological and psychological mechanisms implicated in COVID-19-related psychiatric vulnerability. Even as vaccines drive down rates of infection and death, our perspective will remain relevant to both patients with new-onset mental disorders and those with exacerbation and reactivation of previous psychiatric illnesses. Moreover, those with "long-hauling" non-specific symptoms, as well as individuals impacted by future pandemics with respiratory infections affecting brain and behavior, are expected to benefit from increased understanding and improved readiness. 


\section{Human Coronaviruses}

Currently, there are 7 coronaviruses (CoVs) known to infect humans. These include the $\alpha-\mathrm{CoV}$ genera $(\mathrm{HCoV}-229 \mathrm{E}$ and $\mathrm{NL63}$ ) and $\beta$-CoV genera in the Coronaviridae family (HCoVOC43 and HCoV-HKU1), which cause only mild respiratory disease and three coronaviruses (severe Middle East respiratory syndrome (MERS-CoV), severe acute respiratory syndrome coronavirus 1 (SARS-CoV-1), and SARS-CoV-2) that cause severe illnesses with respiratory and systemic symptoms in a significant proportion of patients [4]. Prior to the SARS-CoV-1 outbreak in 2003, the human coronaviruses were known only to cause symptoms associated with the common cold.

The coronaviral genome codes for four major structural proteins: (1) the spike (S) protein, which mediates attachment to the host cell surface receptors and viral penetration; (2) the membrane (M) protein, which defines the solar corona-like shape of the viral envelope; (3) the envelope (E) protein, which participates in viral assembly and release; and, (4) the nucleocapsid (N) protein, which binds to the RNA genome and is also involved in viral assembly and release [4]. Coronaviruses possess the largest genome of RNA viruses [4]. Notable characteristics of SARS-CoV-2 include its potential use of the CD147 cluster of differentiation (CD) to aid in cell entry [5], the presence of a specific furin-like cleavage site in its $\mathrm{S}$ protein [6••], and in comparison to SARS-CoV-1, its stronger binding affinity to the human angiotensin I-converting enzyme 2 (ACE2) [6••].

\section{Immune Response to SARS-CoV-2}

The immune response to viral peptide presentation (on the surface of invaded cells by class I major histocompatibility complex (MHC) proteins) leads to differentiation and activation of $(\mathrm{CD}) 8+$ cytotoxic $\mathrm{T}$ cells, which begin clonal expansion and differentiation in virus-specific effector and memory $\mathrm{T}$ cells, leading to lysis of virus-infected tissue cells [7]. This further leads to the virus and its particles being recognized by antigen-presenting cells (i.e., dendritic cells and macrophages) and B cells being activated, which then interact with $\mathrm{CD} 4+\mathrm{T}$ cells, further enhancing $\mathrm{CD} 8+\mathrm{T}$ cell expansion [7]. This is why impaired induction of $\mathrm{T}$ cell proliferation and $\mathrm{T}$ cell function in COVID-19 $[8,9 \bullet \bullet]$ contributes to reduced viral clearance and prolonged immune activation. T cell counts have been noted to be significantly reduced in COVID-19 patients, especially those hospitalized in intensive care units (ICUs), with surviving T cells appearing functionally exhausted (expressing higher levels of inhibitive checkpoint markers programmed cell death 1 (PD-1) and hepatitis A virus cellular receptor 2 (TIM-3))
$[8,9 \bullet \bullet]$ This effect on $\mathrm{T}$ cells greatly reduces immune surveillance and allows the virus to hematologically circulate, especially within monocytes.

Such a reduction in the adaptive immune response results in a greater dependence on innate immune cells, such as macrophages, for elimination of SARS-CoV-2. Angiotensin I-converting enzyme 2 (ACE2) expressing CD68 + CD169 + macrophages containing SARSCoV-2 have been shown to produce a significant amount of the cytokine, interleukin (IL)-6, suggesting that they may contribute to the dysregulated inflammatory response in COVID-19 [10]. Additionally, macrophage activation syndrome may further explain the high serum levels of C-reactive protein (CRP), which are not normally present among those with viral infections, as well as cytokine storms observed among those with COVID-19 [11]. Infection with COVID-19 also induces a population of phenotypically distinct $\mathrm{CD} 14^{+} / \mathrm{CD} 16^{+}$inflammatory monocytes that secrete proinflammatory cytokines, including IL- 6 and tumor necrosis factor alpha (TNF $\alpha$ ) [12]. COVID-19 virulence and pathogenicity have been associated with activation of an inflammasome (i.e., NOD-like receptor pyrin domain containing 3 [NLRP3] inflammasome) in monocytes, macrophages, and epithelial cells (and maybe even endothelial cells), possibly contributing through the release of proinflammatory cytokines, IL-1 $\beta$ and IL-18. Also, toll-like receptor (i.e., TLR3, TLR7, TLR8, and TLR9) interactions with SARSCoV-2 RNA activate the nuclear factor kappa B (NF- $\mathrm{kB}$ ) pathway, which contributes to a release of proinflammatory cytokines [13]. Some evidence also suggest that SARSCoV-2 interacts with CD147, a receptor on host cells that is the main upstream stimulator of matrix metalloproteinases (MMPs), with expression levels of CD147 and MMPs often being increased in inflammatory processes [14].

During an immune response, B cells are stimulated by CD4 + T helper cells to differentiate and secrete antibodies (i.e., immunoglobulins (Ig)) with specific antigen-binding fragments $(\mathrm{Fab})$ and fragment crystallizable $(\mathrm{Fc})$ regions (i.e., $\operatorname{IgM}, \operatorname{IgG}, \operatorname{Ig} \mathrm{A}$, or $\operatorname{IgE}$ ) [15]. The Fab region of antibodies is involved in neutralizing the antigen by binding to it, while the $\mathrm{Fc}$ regions are involved in the effector functions through interaction with complement proteins, lectin-like proteins, and $\mathrm{Fc}$ receptors (which are present on all innate immune cells) [15]. The effector functions include phagocytosis (of infected cells and pathogens bound by antibodies) by monocytes, macrophages, neutrophils, and dendritic cells, as well as the killing of infected cells via cytotoxic natural killer (NK) cells and complement-mediated lysis [15]. During viral infection, the majority of neutralizing antibodies target the viral spike glycoproteins and thus prevent virus entry to the cell. Some antibodies also bind glycoproteins to the infected cell's surface, thus preventing viral 
budding [16]. Evidence shows that individuals develop both IgM and IgG antibodies to the SARS-CoV-2 spike receptorbinding domain and nucleoprotein, with higher titers noted among individuals who experienced a more severe course of COVID-19 [17-20]. Further, a recent study shows that in COVID-19 patients with neurological symptoms, intrathecal immune responses are distinct from peripheral responses, with CSF antibodies targeting antiviral and antineural antigens [21].

\section{Sex Differences in Immune Response to SARS-CoV-2}

Male sex has been associated with a higher rate of infection with SARS-CoV-2 [22] and negative COVID-19 outcomes, including death [23-25]. This may be related to biological differences in the innate and adaptive immune responses to infection, which are influenced by genes, hormones, and the microbiome [26]. Males with COVID-19 have higher plasma levels of innate immune cytokines (e.g., IL-8 and IL-18) and $\mathrm{CD} 14^{\mathrm{lo}} \mathrm{CD} 16^{+}$non-classical monocytes than females with COVID-19 and healthy controls [27]. Females with COVID-19 have more CD4 and CD8 T cell activation than males (with a greater difference in CD8 T cells), and a poor $\mathrm{T}$ cell response was found to be negatively correlated with age and associated with worse disease outcomes in males (but not in females) [27]. Additionally, males with COVID19 have higher levels of neutralizing IgG antibodies against the SARS-CoV-2 S protein [28].

\section{Mechanisms of CNS Penetration by Coronaviruses}

The coronaviruses have neuroinvasive potential, being able to reach the central nervous system (CNS) via neural retro-

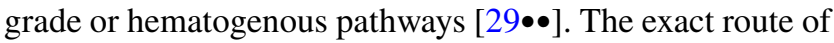
entry of SARS-CoV-2 into the CNS remains to be identified, but several pathways have been proposed that are analogous to mechanisms reported among those with other viral infections $[30,31]$.

\section{Neural Pathway of CNS Penetration by Coronaviruses}

The olfactory neuroepithelium located inside the nasal cavity is one of the regions in which CNS neurons are in direct contact with the external environment. This allows pathogens and molecules to access the CNS, while circumventing the blood-brain barrier (BBB) (whose tight junctions prevent passage of cells and large molecules) and the systemic circulation (where immune surveillance neutralizes or kills foreign antigens) [30]. The intranasal pathway has been previously shown to be a direct access route to the CNS for several neurotropic viruses including arena [32], Borna disease [33], herpes simplex (HSV) [34], influenza [35] mumps [36], and measles viruses [37] (Fig. 1).

Recent studies demonstrate that SARS-CoV-2 also invades the CNS by infecting and bypassing the olfactory neuroepithelium [38]. In the context of viral rhinitis, coronaviruses can disrupt the nasal epithelium and reach the CNS through neural dissemination (e.g., olfactory tract [31]). Retrograde transport of viral antigens along the axons of olfactory sensory neurons is suggested by mouse models transgenic for human ACE2 and intranasally inoculated with SARS-CoV-1 $[9 \bullet \bullet]$. This is congruent with ACE2 expression in human olfactory epithelium and SARS-CoV-2 posi-

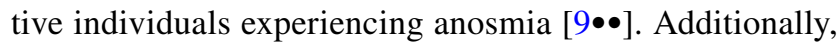
neuropilin-1 (NRP1), which is present on olfactory neuronal cells inside the nasal cavity, provides an additional molecular receptor for SARS-CoV-2 entry [39••].

Axonal transport results in neuron-to-neuron propagation of coronaviruses, as seen in $\mathrm{HCoV-OC43} \mathrm{[40].} \mathrm{In} \mathrm{experi-}$ mental murine models, manifestations vary from flaccid paralysis to encephalitis depending on mutations in the spike glycoprotein of the virus [41] and involvement of glutamate excitotoxicity [42]. Notably, in humanized murine models, the SARS coronaviruses can cause neuronal death in the absence of encephalitis [43]. Additionally, the $S$ protein of SARS-CoV-2 has been shown to be able to cross the BBB in mice [44]. Besides the olfactory "superhighway from the nose to the brain [30]," the coronaviruses can also use other cranial nerves as substrates for axonal transport [40].

The presence of SARS-CoV-2 in the cerebrospinal fluid (CSF) further supports direct invasion of the CNS by the virus [45]. The presence of SARS-CoV-2 in the CSF of individuals with neuropsychiatric symptoms has been noted in case reports from an individual with meningoencephalitis and seizures [46], an individual diagnosed with viral encephalitis in China [47], and another case with suspected demyelinating disease [48]. A 47-year-old individual with cerebellar dysfunction was found to have edema of the cerebellar hemisphere associated with leptomeningeal enhancement on brain magnetic resonance imaging (MRI), and subsequently, SARS-CoV-2 RNA was detected in oropharyngeal/nasopharyngeal and CSF specimens [49]. In another case, an individual with COVID-19 pneumonia, meningoencephalitis, and nephritis had detectable SARSCoV-2 in his CSF, but not in his peripheral blood, further suggesting that SARS-CoV-2 can invade the CNS without circulating through the blood [50]. The cell count in the CSF of this individual was low, which may be due to the lymphopenia that has been previously described in COVID-19 [50]. In a case of a 55-year-old woman with acute necrotizing encephalitis, the CSF was initially negative for SARS-CoV-2 


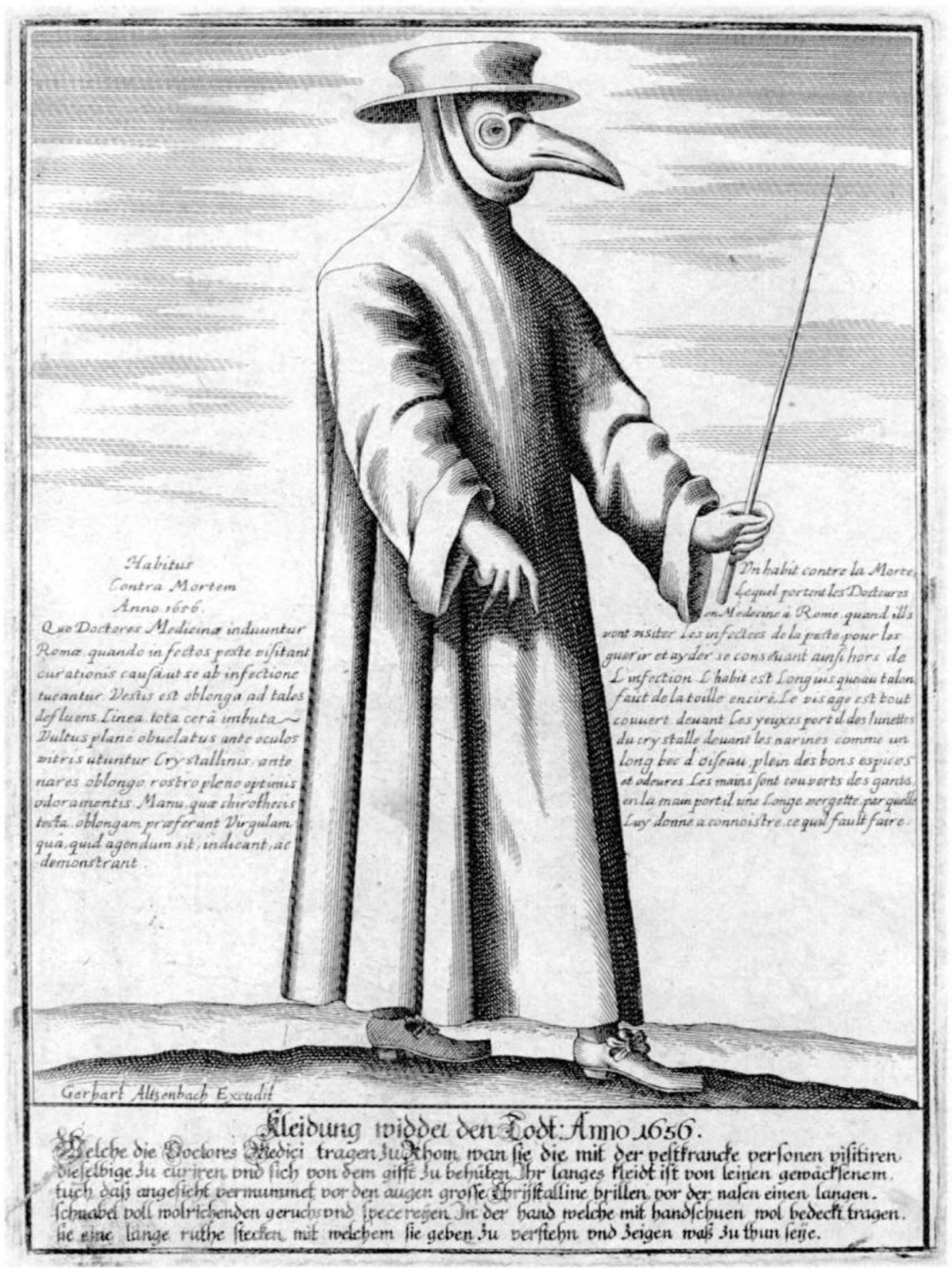

Fig. 1 Historic awareness of the importance of the nasal pathway in pandemics. Legend: The Plague Doctor is a reproduction of a 1856 engraving by the publishing house of Gerhart Altzenbach, a copper engraver from Cologne, Germany (approximately 1590-1672) illustrating a 1656 outfit of a physician during the medieval outbreaks of plague that spread throughout Rome and neighboring Naples. The outfit is representative of what doctors wore during the bubonic plague in Europe in hopes of protecting themselves from the disease. Protecting the nostrils and shielding the eyes were believed to be paramount. The physicians held wands to better give instructions. The beak of the mask was often filled with strongly aromatic herbs and spices with potential disinfectant effects, in hopes of protection from the miasmas or "bad air," which at the time was thought, mistakenly, to carry the plague. Nevertheless, the intuition about the importance of the nasal pathway proved correct for other infectious disease. Indeed, the nose is a common "superhighway" to the brain for certain pathogens, including coronaviruses, to enter the central nervous system [30] (Tonelli, L. H. and Postolache, T. T. 2010), including for coronaviruses, such as COVID-19. (The picture of this engraving, The Plague Doctor, is in the public domain and was published in circa 1656 by Gerhart Altzenbach. REPRODUCED FROM https:// commons.wikimedia.org/wiki/File:Gerhart_Altzenbach,_Kleidung widder_den_Todt_Anno_1656.png. ACCESSED ON 12.20.20. Original capture: Tizenberg et al.) 
RNA twice but was detected in the CSF 19 days after symptom onset [51]. Additionally, despite the individual's neurological function declining to the point of coma, and exceptionally elevated concentrations of the neuronal injury markers (i.e., neurofilament light-chain protein and tau protein) and astrocytic activation marker (i.e., glial fibrillary acidic protein) in the CSF, the monocyte and protein levels in the CSF were only marginally increased, and there was no evidence of a hyperinflammatory state, further supporting the neuroinvasiveness of SARS-CoV-2 [51]. In a case of a 49-year-old woman with meningitis, SARS-CoV-2 was detected in the CSF, but chest computed tomography (CT) revealed a lack of pulmonary involvement, and oropharyngeal/nasopharyngeal samples were negative for the presence of the virus [52]. A 64-year-old woman began to experience symptoms of acute meningoencephalitis several weeks after resolution of COVID-19 associated respiratory distress (her nasopharyngeal swab for SARS-CoV-2 was negative) at which time her CSF, nasopharyngeal, and tracheal aspiration specimens tested positive for SARS-CoV-2 [53].

However, in many cases, SARS-CoV-2 was not detected in the CSF [54-56]. A retrospective analysis of individuals with COVID-19 found that SARS-CoV-2 RNA was detected in CSF in 1 out of 28 cases [57] and a review found the CSF detection of SARS-CoV-2 as $1.28 \%$ among 1018 cases pooled from case reports and case series that obtained CSF samples [45].

There is also post-mortem data from several studies of autopsies that looked for neuropathological findings or the presence of SARS-CoV-2 in the brain. Three of these studies did not find the presence of SARS-CoV-2 in the CNS across 12 cases of confirmed COVID-19 [58-60]. However, nine studies across 58 of 87 cases (67\%) found SARS-CoV-2 RNA in the brain [39••, 56, 61-67]. It is important to note that, although in one of the studies SARS-CoV-2 RNA was found in 9 of 11 cerebral samples, autopsy examination did not show evidence of viral encephalitis nor vasculitis [61], which could suggest that the polymerase chain reaction (PCR) result may have been a false positive. Another case confirmed by reverse transcription polymerase chain reaction (RT-PCR) showed neuronal damage on autopsy, which was progressively less severe from the olfactory nerve to the gyrus rectus and to the brainstem, also supporting the theory of direct invasion of the CNS by SARS-CoV-2 through the olfactory mucosa [68]. In brain autopsies of three individuals who died from COVID-19, there was evidence of the presence of SARS-CoV-2 in endothelium and cortical neurons, but there was no evidence to suggest lymphocyte or leukocyte infiltration [69].

Brain MRI of individuals with COVID-19 has also demonstrated structural changes in the olfactory pathway, including the olfactory nerve, olfactory bulb, and cortex, further supporting the concept of SARS-CoV-2 following this pathway in a retrograde manner to the CNS [70-72].

Human brain organoid models have shown evidence for infection of neurons by SARS-CoV-2, with secondary changes within infected and nearby neurons [69]. The brain organoid models also showed that ACE2 blocking antibodies can prevent SARS-CoV-2 infection, further supporting that ACE2 may play a significant role in neuroinvasion [69].

Animal studies with immunostaining for SARS-CoV-2 showed enhancement in brain regions connected to the olfactory bulb $[73,74]$ and suggest that SARS-CoV-2 can invade the CNS via retrograde olfactory, gustatory, and trigeminal pathways [74]. A mouse model found that expressing human ACE2 receptor in the brain involved weight loss and death after intranasal or intrathecal introduction of SARS-CoV-2, while the mice expressing human ACE2 receptor in the lungs did not experience weight loss or death after inoculation with the virus [69].

SARS-CoV-2 may also enter the CNS through retrograde transport along the vagus nerve and its branches. Enterocytes in the GI tract and inhibitory enteric neurons (which the vagus nerve synapses on) were found to co-express ACE2 and proteases associated with SARS-CoV-2 entry (i.e., transmembrane protease serine 2 (TMPRSS2) and cathepsin L (CTSL)) [75], and SARS-CoV-2 has been shown to effectively replicate inside enterocytes [76].

Some researchers have expressed doubt that the virus uses the neural pathway to enter the CNS. For example, a preprint article documenting 67 autopsies on COVID-19-positive patients noted that the most striking features in the neuropathological examination were vascular (i.e., presence of microthrombi and acute infarction), and even though two cases suggested the beginning of encephalitis (i.e., focal parenchymal infiltrate of T-lymphocytes), the authors commented that widespread meningoencephalitis, microglial nodules, and viral inclusions were not a prominent feature in any of the cases [77]. Moreover, the authors affirm that the absence of meningoencephalitis, microglial nodules, and viral inclusions from the olfactory bulbs and brainstem argues against nasal entry - and there was also no loss of myelin to suggest demyelination [77]. The authors also noted elevated inflammatory markers, abnormal coagulation values, elevated proinflammatory cytokines (IL-6, IL-8, and $\mathrm{TNF} \alpha$ ), microthrombi in multiple organ systems including the brain, the presence of the virus and the ACE2 receptor in the brain, and a macrophage activation syndrome [77]. Another case report documented difficulty in detecting the virus in the CSF of two stroke patients positive for SARSCoV-2 [54]. This is not surprising as the virus does not need to be in the CSF or brain parenchyma to cause coagulopathies and stroke, as all these effects could be consequences of systemic dysregulation. 
Nevertheless, more recent evidence does support the view that SARS-CoV-2 may enter the CNS through the nasal epithelium. Single-cell sequencing showed that ACE2 is expressed in support cells, stem cells, and perivascular cells in the olfactory epithelium and olfactory bulb, rather than in neurons, which was confirmed by immunostaining in a mouse that also showed widespread expression of ACE2 in dorsally-located olfactory epithelial sustentacular cells and olfactory bulb pericytes [78]. Additionally, SARS-CoV-2 $\mathrm{S}$ protein and RNA presence were the highest in olfactory mucosa (directly beneath the cribriform plate) as compared to the olfactory bulb, olfactory tubercle, oral mucosa (i.e., uvula), trigeminal ganglion, medulla oblongata, and cerebellum [38]. This, in combination with the presence of SARSCoV-2 S protein in cerebral and leptomeningeal endothelial cells, suggests that neuroinvasion may also occur at the olfactory mucosa and follows regional neuroanatomical structures [38].

\section{Hematological Pathway of CNS Penetration by Coronaviruses}

Coronaviruses are selective in terms of which immune cells they exterminate (e.g., dendritic cells) and which cells they protect (i.e., monocytes [79], and activated type 1 macrophages (M1) after stimulation with lipopolysaccharide (LPS) [80]). Coronaviruses, especially SARS-CoVs, can infect immune cells [79, 81-86] and use them as a reservoir from which they can hematogenously disseminate to other tissues and organs, including the CNS [29••, 87]. Specifically, the monocytes infected by coronaviruses can bypass the BBB, allowing the virus to enter the CNS and

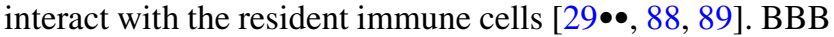
permeability is altered by microglia and invading macrophages (during pathologic conditions) and their release of cytokines and gliotransmitters [90]. This may increase BBB permeability in COVID-19 and allow even more leukocytes to migrate to the CNS. Post-mortem analysis of patients who died from severe COVID-19 revealed significant lymphocytic apoptosis and that ACE2-expressing CD68 + CD169 + macrophages contained SARS-CoV-2 nucleoprotein antigen and showed upregulation of IL-6 [91]. This suggests that CD169+macrophages could contribute to viral spread, excessive inflammation, and lymphocytic cell death during SARS-CoV-2 infection.

\section{Role of ACE2 in COVID-19}

The virus spreads throughout the body via the ACE2 receptor expressed broadly in many cells, in particular, pneumocytes and endothelial cells across multiple organs; however, in the brain, ACE2 is not limited to the vasculature but includes monocyte-derived macrophages, brain microglia, and neurons [43, 92]. SARS coronavirus infections involve a major priming step, which determines tissue tropism and host compatibility - the S protein cleavage by host proteases. Despite its resemblance to SARS-CoV-1, SARSCoV-2 contains in its $S$ protein a specific furin-like cleavage site [93]. It has been previously shown that host furin-like cleavage proteases and furin-like cleavage sites determine disease phenotype and neurotropism [94]. It is possible that a furin-protease mutation that upregulates function does not increase invasion of the coronavirus strain $\mathrm{O} 43(\mathrm{HCoV}$ O43) but decreases the egress of the virus, resulting in a less pathogenic but persistent CNS infection. This mechanism is consistent with a resilient course of the neuropsychiatric pathology previously seen in CNS infections. Additionally, the SARS-CoV-2 S protein binds the host receptor up to 10 times more tightly than the $\mathrm{S}$ protein of SARS-CoV-1, suggesting a possible explanation for the differences in spread, morbidity, and mortality from the two viruses [6••].

However, it is important to note that HCoV's binding to ACE2 is not necessary for severe respiratory illness, nor for development or exacerbation of neurological and psychiatric disorders. MERS-CoV-1 does not use ACE2 to gain intracellular access and still causes severe respiratory illness and may lead to neurological and psychiatric outcomes [95••]. In contrast, despite causing only a benign upper respiratory illness, HCoV-NL63 binds to ACE2 and HCoV-NL63 seropositives are more likely to develop mood disorders [96].

\section{Neuropsychiatric Symptoms in COVID-19: Acute, Late, and Persistent Manifestations}

\section{Acute Manifestations}

The presentation of COVID-19 is highly heterogeneous, including neuropsychiatric symptoms [97]. An increased incidence of a first psychiatric diagnosis 14 to 90 days after diagnosis of COVID-19 has been noted, with a higher risk than for other infections [98••]. With regard to the CNS, of 841 patients hospitalized with COVID-19 in the ALBACOVID registry of the Spanish population, more than half developed some kind of neurological symptom, with the most common and early presentation being non-specific symptoms (i.e., myalgias, headache, and dizziness). Furthermore, acute neurological complications were the main cause of death in $4.1 \%$ of all deceased study subjects [99]. A study found that over a third of hospitalized patients in Wuhan, China, experienced neurological involvement (e.g., acute cerebrovascular diseases, impaired consciousness, or skeletal muscle injury), which were more likely in those who experienced a severe course of COVID-19 [100]. 


\section{Acute Peripheral Nervous System Manifestations}

In the peripheral nervous system (PNS), anosmia and ageusia (without congestion) are some of the more common early symptoms [100], which were more frequent in less severe cases $[99,101]$. A multicenter European study noted that more than $3 \%$ of individuals with confirmed SARS-CoV-2 still experienced hyposmia or anosmia after 15 days [101].

\section{Acute CNS Symptoms in COVID-19}

An early case series from a hospital in France noted that neurologic features (e.g., delirium, corticospinal tract signs, and acute ischemic stroke) were present in more than half the patients who tested positive for SARS-CoV-2 [102]. Delirium (i.e., disorders of consciousness or acute encephalopathy) is common, seen mostly in older patients and in severe cases of COVID-19 and seems to be associated with systemic inflammation [99]. A meta-analysis of neuropsychiatric presentations associated with coronavirus infections (including data from SARS-CoV-2) found that delirium was common in severe cases-confusion was reported in 65\% (of individuals in an intensive care unit), agitation in 69\% (of individuals in an intensive care unit), and altered consciousness in $21 \%$ (of individuals who later died) [95••]. Severe SARS-CoV-2-related delirium often presents as global brain dysfunction with a reduced level of sensorium, which may rapidly progress to a persistent comatose state. Fluctuating alertness and orientation are common, with the picture occasionally dominated by agitation, irritability, and delusions that are less responsive to traditional antipsychotics. Onset is frequently concurrent with a rapid increase in serum levels of acute phase reactants and proinflammatory

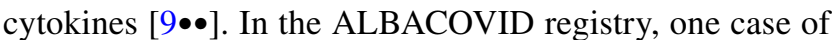
encephalitis was reported [99], a COVID-19-associated Acute Necrotizing Encephalopathy (ANE) [103] case was reported, and a COVID-19-associated viral encephalitis was reported in a young man [46]. Additionally, there are several case reports of acute myelitis associated with COVID-19 [104-107]. Seizures have also been reported in COVID-19 patients [99, 100, 108].

Both ischemic and hemorrhagic [109] strokes have been observed in patients with COVID-19 and are more likely to be seen in individuals experiencing a more severe course of disease, with cardiovascular disease (CVD) risk factors (e.g., hypertension, diabetes, and history of CVD), increased inflammatory response, and hypercoagulable state (as reflected in CRP and D-dimer levels) [99, 100, 110]. A cohort study in the NYU Langone Health system noted a mean age of 61.6 years for COVID-19-positive patients with intracranial hemorrhage [109], and a systematic review found a mean age of 63.4 for acute ischemic stroke [111]. There are also several documented cases of SARS-CoV-2-positive individuals with large vessel stroke who are under 50 years old [112]. Retrospective studies from Italy and China indicate that acute cerebrovascular events have been diagnosed in 3\% of individuals with COVID-19 and in 6\% of individuals with severe COVID-19 [113].

\section{Acute Clotting Disorders in COVID-19}

The occurrence of ischemic strokes $[99,100,110]$ as well as the predominance of vascular neuropathlogic findings (i.e., microthrombi, acute infarction) found in autopsies [77] of individuals with COVID-19 are significant causes of concern for potential morbidity and mortality. This leads to the question-are there hemostatic abnormalities induced in SARS-CoV-2 infection? And indeed, when SARS-CoV2-positive individuals were compared to healthy controls, they showed lower anti-thrombin values and lower prothrombin time activity, much higher D-dimer, fibrin/ fibrinogen degradation products (FDP), and fibrinogen (FIB) values; D-dimer and FDP values in individuals with severe SARS-CoV-2 infection were higher than those in individuals with milder forms, and thrombin time in critical SARS-CoV-2-positive individuals was also shorter [114]. Non-survivors of COVID-19 had similar observations when compared to survivors i.e., higher D-dimer and FDP levels, and longer prothrombin time activity and activated partial thromboplastin time on admission [115]. Additionally, almost three out of four non-survivors and less than $1 \%$ of survivors met the criteria of disseminated intravascular coagulation [115]. Three individuals in one ICU were noted to have multiple cerebral infarctions, and their serology showed the presence of anti-cardiolipin $\operatorname{IgA}$ antibodies, and anti- $\beta 2$-glycoprotein I IgA and IgG antibodies, which are major components of antiphospholipid syndrome and have also been shown to be transiently elevated in some infections and severe illness [116].

\section{Acute Endotheliitis and Pan-organ Involvement in COVID-19}

The endothelium is not only a barrier, but also a paracrine, autocrine, and endocrine organ with functions necessary for adequate vascular flow. Its dysfunction leads to a procoagulant state and vasoconstriction, which can cause ischemia and stroke, as well as inflammation, tissue edema, and impaired barrier function. These changes then allow for translocation of immune cells and molecular 
mediators. There is evidence for direct invasion in COVID19 of endothelial cells, with development of local inflammation, apoptosis, and pyroptosis leading to widespread endotheliitis and microcirculatory dysfunction [117].

Individuals with COVID-19 in the ICU had significantly higher circulating endothelial cell (CEC) levels than those with the disease but not in the ICU, and the extent of endothelial injury negatively correlated with platelet and lymphocyte count and positively correlated with inflammation-induced endothelial adhesive molecules [e.g., E-selectin and soluble vascular cell adhesion molecule-1 (sVCAM-1)], which is evidence of the presence of endothelial injury in COVID-19 [118].

\section{Subacute and Late Manifestations of COVID-19}

According to one meta-analysis, in the post-illness stage of infection with coronaviruses (including data from SARS-CoV-2), the prevalence of PTSD was $32.2 \%$, that of depression was $14.9 \%$, and that of anxiety disorders was $14.8 \%$ (11.1-19.4; 42 of 284 cases from three studies) [95••]. Additionally, $76.9 \%$ of individuals had returned to work at a mean follow-up time of 35.3 months [95••]. There is specific concern for PTSD, as increased risk was seen in MERS and SARS survivors and PTSD is known to occur in individuals who experience similar hospital courses (i.e., admission to ICU, intubation and mechanical ventilation, or delirium) [119].

A multicenter retrospective cohort study in China found that almost one-third of individuals who tested positive for SARS-CoV-2 screened positive for clinical anxiety at discharge from the hospital, with a higher risk for survivors of severe COVID-19 [120]. In the USA, an association was found between COVID-19 diagnosis and psychiatric disorders, with the incidence of any psychiatric diagnosis 14 to 90 days after COVID-19 diagnosis seen in almost one in five individuals and one in 20 receiving their first diagnosis $[98 \bullet \bullet$. The greatest risk was for anxiety disorders, insomnia, and persistent cognitive deficits [98••]. Similar results were found in samples of COVID-19 survivors in Shenzhen, China [121], and Milan, Italy [122••].

Psychotic symptoms related to SARS-CoV-2 infection have also been observed in individuals with no previous history of neuropsychiatric disorders. Notably, a surveillance study in the UK found that $43 \%$ of individuals who experienced neuropsychiatric symptoms from COVID-19 had new onset psychosis [123]. A 36-year-old woman with no individual or family history of mental illness experienced psychotic symptoms 4 days after the onset of upper respiratory symptoms from confirmed and mild COVID-19 [124]. Her psychotic symptoms improved after treatment with antipsychotics and benzodiazepines, and after discharge, the patient discontinued the medication without return of psychotic symptoms [124]. There are also case reports of individuals for whom psychotic symptoms persisted longer [125]. Although there have been reports of individuals experiencing new onset psychotic symptoms after testing positive for SARSCoV-2 despite having no upper respiratory symptoms, these were associated with elevated peripheral inflammatory markers (e.g., CRP) [126]. It is likely that severity of COVID-19 or possibly the intensity of psychological trauma linked with severity of illness is associated with new onset psychosis.

\section{Persistent Symptoms of COVID-19}

An outpatient study in the USA reported that among individuals who tested positive for the virus, $94 \%$ reported experiencing one or more symptoms at the time of testing, and $35 \%$ of these symptomatic patients had not returned to their baseline state of health two to three weeks later, with cough, fatigue, or shortness of breath being the most common lingering symptoms [127]. A 3-month follow-up study of COVID-19 survivors, who notably did not experience a severe course of the illness, noted that 39 out of 55 patients had different degrees of pulmonary radiological abnormalities [128]. A French study noted that many patients after experiencing mild symptoms attributable to COVID-19 have a resurgence of persistent symptoms, including myalgia, intense fatigue, sensation of fever, shortness of breath, chest tightness, tachycardia, headaches, and anxiety [129]. Consistently, in Italy, 2 months after initial onset of COVID-19 symptoms, more than half of the individuals continued to experience fatigue, almost half still experienced shortness of breath, and almost onethird still experienced chest pain [130]. A follow-up study of discharged COVID-19 patients in Italy found that $87.4 \%$ of patients reported persistence of at least one symptom, $32 \%$ had one or two symptoms, and $55 \%$ had three or more [131]. The authors found that $44.1 \%$ of patients reported worsened quality of life, and the most common reported persistent symptoms were fatigue $(53.1 \%)$, dyspnea $(43.4 \%)$, joint pain, $(27.3 \%)$, chest pain $(21.7 \%)$, and anosmia $17.5 \%$ [131]. Another study reported that among individuals diagnosed with COVID-19 with initial anosmia, only $74 \%$ reported resolution of anosmia with clinical resolution of initial illness [132]. The progression from anosmia/hyposmia to parosmia also impacts COVID-19 survivors' quality of life [133]. Based on a systematic review, olfactory training (stimulation, retraining, rehabilitation) is the primary recommendation for management of post-infectious olfactory dysfunction [134••]. Persistent PNS manifestations of "long" COVID-19 have also been reported, including myopathy, dysautonomia, movement disorders, Guillain-Barré syndrome, and optic neuritis 
[99]. Among survivors assessed 29 to 71 days postdischarge from a university hospital in the UK, $72 \%$ of individuals hospitalized in an ICU continued to report fatigue as compared to $60.3 \%$ hospitalized in a ward, $65.6 \%$ hospitalized in an ICU vs. $42.6 \%$ in a ward reported shortness of breath, and $46.9 \%$ hospitalized in an ICU vs. $23.5 \%$ in a ward continued experiencing psychological distress [135]. A 6-month cohort study in China found that $63 \%$ of individuals continued to experience fatigue or muscle weakness after resolution of the initial symptoms of confirmed COVID-19 [136••]. This study also found that difficulties with sleep were reported by $26 \%$ of individuals, and $23 \%$ of people reported experiencing anxiety or depression $[136 \bullet \bullet]$.

Autonomic dysfunction has been posited as a contributor of morbidity and mortality from COVID-19 via excessive sympathetic activity, the vagal anti-inflammatory reflex, and psychological stress and may also help explain persistent symptoms [137•]. A case series describes females between the ages of 26 and 50 who experienced orthostatic intolerance (with either resting or postural hypotension and tachycardia) after resolution of initial upper respiratory or gastrointestinal symptoms [138•]. Another 26-year-old woman experienced orthostatic intolerance and spells of sympathetic hyperactivity for months after confirmed SARS-CoV-2 infection and was confirmed to have postural tachycardia syndrome [139]. An additional case report describes a 20-year-old man who tested positive for SARS-CoV-2 and presented with mild symptoms of COVID-19 and dysautonomia, including orthostatic hypertension, loss of sinus arrhythmia without any ischemic changes on electrocardiogram, and hypotonia [140]. The autonomic dysfunction was further confirmed with Valsalva maneuver and isometric hand grip exercises, and 1 month after intravenous immunoglobulin and physiotherapy, the patient was able to walk with assistance [140]. A 72-year-old individual who tested positive for SARS-CoV-2 experienced fluctuating blood pressures during his hospitalization and was noted to have diminished cough and gag reflexes [141]. It has been proposed that the persistent autonomic dysfunction is a consequence of the inflammatory response to the virus, with cytokines activating autonomic nerves and the hypothalamic-pituitaryadrenal axis [142].

Some of the persistent symptoms (i.e., fatigue, brain fog) resemble myalgic encephalomyelitis/chronic fatigue syndrome (ME/CFS). ME/CFS has often been documented following an infection, and serological information (e.g., antinuclear antibody (ANA), anti-double-stranded deoxyribonucleic acid (anti-dsDNA), and anti-ganglioside antibodies) from some patients has suggested an autoimmune pathophysiology, at least for a subset of patients with the disease [143].

\section{Neuropsychiatric Disorders and Vulnerability to COVID-19}

Individuals with a previous history of neuropsychiatric disorders may be particularly vulnerable to experiencing a severe course of COVID-19, to be hospitalized and to suffer a COVID-19 associated death. A meta-analysis showed that for individuals who tested positive for SARS-CoV-2, a prediagnosis of a mental disorder increased their risk of COVID-19 mortality and severity, which remained significant after adjustment for confounding variables [144]. Specifically, the meta-analysis found higher mortality for individuals with schizophrenia and schizotypal and delusional disorders as compared to mood disorders [144].

In the USA, individuals with a recent (within 1 year) diagnosis of a mental disorder had a significantly increased risk for SARS-CoV-2 infection, with an adjusted odds ratio greater than seven for both depression and schizophrenia [2]. Among individuals with mental disorders, racial and ethnic disparities continued to play a role, with African Americans having higher odds of COVID-19 infection than Caucasians and women having higher odds of COVID-19 infection than males [2]. In addition, individuals with a recent diagnosis of a mental disorder and SARS-CoV-2 infection experienced a death rate of $8.5 \%$ and a hospitalization rate of $27.4 \%$, as compared to 4.7 and $18.6 \%$ respectively, among individuals with SARS-CoV-2 and no mental disorder [2].

Notably, a cross-sectional study found that individuals with previous psychiatric disorders and those with both psychiatric and physical disorders had lower odds of screening positive for SARS-CoV-2 than individuals with only physical disorders [145]. A retrospective analysis of medical records in Southeast Wisconsin also found that individuals with mental illness had lower odds of testing positive for SARS-CoV-2 [146]. This retrospective analysis also found that individuals with bipolar or substance use disorders that tested positive had much higher odds of being hospitalized, and individuals with bipolar disorder had a significantly higher risk of mortality [146].

A cohort study of a five hospital system in the Northeastern United States found that risk for COVID-19 related hospital death was greater for individuals with any prior psychiatric diagnosis, even after adjusting for demographic characteristics, other comorbidities, and hospital location [147].

Individuals in Denmark who tested positive for SARSCoV-2 were found to have a much higher chance of dying and experiencing severe COVID-19 if they were previously diagnosed with a schizophrenia spectrum, bipolar disorder, or unipolar depression or filled a prescription for psychotropic drugs than individuals without psychiatric disorders [148]. Additionally, a study in Sweden found that individuals with severe mental disorders (e.g., psychotic and 
bipolar disorders) were almost twice as likely to experience a COVID-19 associated death, and these odds increased to four fold for individuals with severe mental disorders between the ages of 60 and 79 years old [149].

It is important to note that neuropsychiatric disorders could be under or undiagnosed and may significantly contribute to a more severe course of COVID-19, hospitalization, and mortality. Analogously, if severe COVID-19 contributes to the development of neuropsychiatric disorders, as has been observed in a 6-month follow-up study [136••], this may lead to a vicious cycle.

\section{The Reciprocal Double-Vulnerability and Sequential Triggering Model for SARS-CoV-2-Induced Psychopathology}

Understanding interactions between predispositions, triggers, and perpetuators, with interplay between biological and psychological factors, of a "stress-diathesis" of psychopathology resulting from or worsened by SARS-CoV-2, leads to an empowered pathophysiological and clinical approach that is geared towards primary and secondary prevention, as well as acute and long-term treatment. Specifically, microglia (innate immune cells in the brain) mediate and regulate the immune responses to pathogens, damage to CNS tissue, as well as intense stress-biologically signaling impending damage to CNS) through signaling molecules (e.g., cytokines, quinolinic acid) that influence neuroplasticity, cognitive function and behavior [150]. Activation of microglia can lead to exaggerated inflammatory responses to stimuli in the brain that would not normally induce a significant inflammatory response, as well as resistance to negative feedback mechanisms that would reduce and shorten inflammation, (i.e., "primed microglia") [150]. This process, while triggered by endogenous and environmental factors, is further synergized by reciprocal potentiating interactions between stress and aging ("inflammaging") $[151 \bullet \bullet, 152]$. There is substantial and increasing evidence linking microglial priming to neuropsychiatric disorders $[150,153]$.

Advanced age, history of autoimmune disease, severe infections, allergy, traumatic brain injury (TBI), severe mental illness, exposure to severe adversity or deprivation during critical developmental times, and obesity result in priming of resident immune cells in the brain and immune overreaction in the context of novel infections, including COVID-19 (see Fig. 2).

Furthermore, an infection with a neurotropic virus, such as SARS-CoV-2, in addition to triggering previous vulnerabilities, could further result in priming of the microglia and astrocytes in the CNS. Thus, COVID-19 could both trigger previously primed substrates and lead to priming mediated vulnerabilities, leading to overreaction to mild proinflammatory stimuli, such as psychological stress, minor pollutants and allergens, and mild infections.

In sum, we have termed the mechanism that we propose to be at the root of chronic neuropsychiatric conditions associated with SARS-CoV-2 as "reciprocal double vulnerability and sequential triggering," meaning that there are predisposing proinflammatory conditions that represent vulnerabilities for the COVID-19 infection to act as a trigger and that the viral infection creates a secondary persistent vulnerability for otherwise mild routine stressors (immune, psychological, traumatic) to act as secondary persistent triggers and perpetuators (see Fig. 2) [98••, 154].

\section{Immunobiological Characteristics of Acute "Psychological" Stressors}

Negative emotions, similar to a repeated physical stressor, upregulate markers of inflammation (e.g., IL-6, CRP), which in turn sensitize the immune system to respond in an amplified way to future stressors [155]. Individuals with chronic stress (e.g., being a caregiver to a relative with cancer) have been noted to have increased levels of inflammatory markers and to have decreased sensitivity of monocytes to glucocorticoids and increased sensitivity of monocytes to NF- $\mathrm{KB}$ (a proinflammatory transcription factor) [156]. Repetitive social stressors also result in peripheral inflammatory myeloid cells that become primed; these peripheral myeloid cells become resistant to downregulation by glucocorticoids, mount an amplified inflammatory response, and travel to organs throughout the body, including the brain [157]. Thus, it is expected that neuroimmune triggering, as well as possibly cellular substrate priming, would emerge from the intense psychological stress during the pandemic. This has stemmed from several sources, including fears associated with COVID-19, social isolation, quarantine, widespread panic, and anxiety [158]. Additionally, outbursts of racism, stigmatization associated with the disease, and xenophobia have been reported [158], further amplifying societal and individual distress. Psychosocial concerns for frontline healthcare workers include burnout, anxiety, fear of transmitting infection, depression, increased substance dependence, and PTSD [158]. Forced disruptions for vulnerable populations (e.g., children, the elderly, psychiatric patients) and their caregivers are especially concerning for psychological consequences [158]. These general stressors of the pandemic may act on the neuroimmune cellular substrates primed by SARS-CoV-2 infection or the immune response to it, resulting in intense and unremitting reactions. Moreover, unavoidable stressors of everyday living, normally below the threshold of activating cellular substrates of inflammation in the brain, succeed doing so with primed substrates, which have a lower threshold for reaction. Thus, the routine 


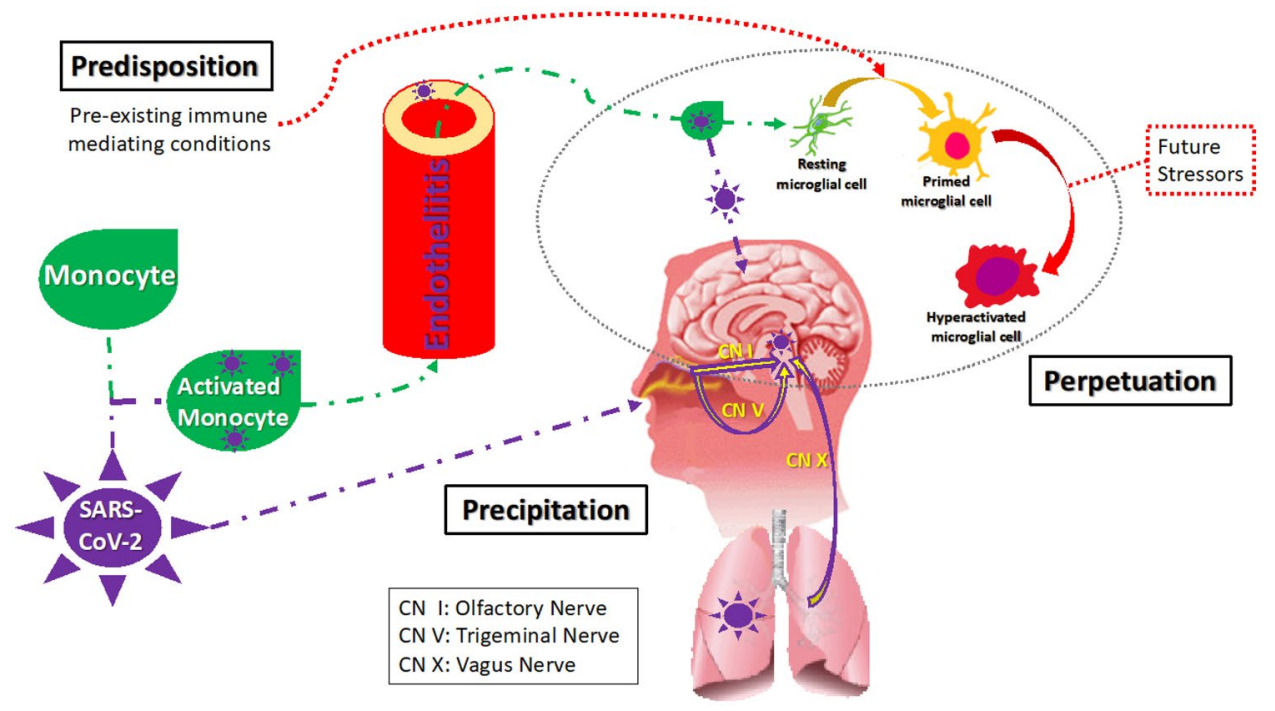

Fig. 2 Reciprocal double vulnerability and sequential triggering. Legend: SARS-CoV-2 precipitates neuropsychiatric symptoms through a reciprocal double vulnerability. The virus can affect the $\mathrm{CNS}$ as part of a pan-organ involvement of endothelia. The virus can affect brain structure and function through direct invasion or via the effects of immune activation and inflammation, including in the choroid plexus [232]. Direct invasion occurs via neural or hematological pathways. The neural pathway is where the virus travels via the olfactory (I) and the trigeminal $(\mathrm{V})$ nerves from the nasal cavity and via the vagus $(\mathrm{X})$ nerves from the lungs to the CNS. From the nose, in addition to nerves I and $\mathrm{V}$, a transepithelial pathway has also been described. The hematological pathway involves the virus traveling via monocytes, cells that deliver the virus through the BBB to the CNS. Both SARS-CoV-2 and inflammatory signals (molecular, cellular) can influence the resident immune cells (e.g., microglia) by priming - a process that involves molecular and structural changes

challenges and mild stressors that are part of the noise of living would succeed to perpetuate mental symptoms in survivors of SARS-CoV-2 infection.

\section{Infection Leading to Autoimmunity}

Infection, directly and through stimulation of the immune response, is also thought to contribute to dysregulated immunity and to be linked with the development of autoimmune disease. The etiology of autoimmune diseases (e.g., type 1 diabetes (DM), multiple sclerosis (MS), rheumatoid arthritis (RA), systemic lupus erythematosus (SLE), inflammatory bowel disease (IBD)) involves genetic components that are thought to be triggered by environmental factors such as vitamin D deficiency, which have also been linked to flares of these diseases [159]. Autoimmune diseases of the CNS are also thought to be triggered by viruses accessing the brain through direct penetration across the $\mathrm{BBB}$, hiding inside mobile immune cells, CSF, and retrograde axonal transport via peripheral and leads to over-reactivity to a multitude of stimuli. The reciprocal double vulnerability and sequential triggering concept postulates that the SARS-CoV-2 can serve both as a trigger of preexisting vulnerabilities (predispositions-including genetic factors, past infections, autoimmune and allergic processes), as well as induce a long-term secondary predisposition, consisting of a vulnerability to triggers that induce, under normal conditions, very mild neuroimmune activation (e.g., routine psychological stressors, mild infections, routine pollutants or allergens, concussions). This results in exaggerated immune, excitotoxic, and apoptotic reactions originating from primed and overactivated microglia [231]. Considering the ubiquity of stressors and exposures of daily living, this can lead to perpetuation of psychiatric syndromes as well as "long-hauling" non-specific symptoms such as headaches, fatigue, sleepiness, sleep abnormalities, and brain-fogginess (original figure and capture, Tizenberg et al.)

nerves and access via the "leaky" choroid plexus responsible for CSF production [160]. Direct penetration of the BBB is not always necessary for development of autoimmunity or immune dysregulation that can affect the CNS. For example, anti-Nmethyl-D-aspartic acid (NMDA) receptor (NMDAR) encephalitis, the most common cause of non-infectious encephalitis, is associated with development of autoantibodies to ovarian teratomas and other tumors, immune checkpoint inhibition for cancer therapy, as well as after viral infection [161-163]. Additionally, CNS inflammation, as seen in acute disseminated encephalomyelitis (ADEM) and acute hemorrhagic leukoencephalomyelitis (AHLE), has been reported to follow infections or vaccinations [164]. The possibility of SARS-CoV-2 triggering an autoimmune reaction is suggested by findings reported in a preprint article, in which the authors noted that their cohort of patients with severe COVID-19 and no previous history of autoimmune disease had shown evidence of de novo autoreactivity (i.e., antinuclear antibodies and rheumatoid factor) [165]. Additionally, the authors suggested that this might occur through TLR7 activation by the single stranded RNA 
of SARS-CoV-2, as a similar pathogenic response has been documented in SLE [165].

\section{Inflammaging, Priming, and COVID-19}

Older age is a significant risk factor for COVID-19 mortality [166]. This may be partially explained by immunosenescence (i.e., reduced production of adaptive immune cells and impaired function of innate immune cells in the elderly, which result in poorer viral clearance and increased chances of immune dysregulation) or"inflammaging" (i.e., chronic subclinical systemic inflammation seen in the elderly) [166].

Immune changes with age are significant for neuropsychiatric disorders because the neuroimmune system becomes primed (i.e., pro-inflammatory). Aged mouse and rat models have demonstrated increased neuroinflammation following peripheral infection [167, 168], especially when compared to younger rodents [168, 169]. Microglial priming has been implicated in these changes [168, 170, 171], suggesting that aging creates a similar vulnerability to development or exacerbation of neuropsychiatric symptoms post-COVID-19 as infectious, mechanical, as well as psychological stressors.

\section{Obesity, Priming, and COVID-19}

Obesity poses additional risk for those affected by SARS$\mathrm{CoV}-2$. A recent meta-analysis showed that severe COVID19 individuals had higher BMIs than non-severe ones and that COVID-19 persons with obesity had higher odds of experiencing a more severe course than those who were not obese [172•]. Obesity may increase the risk for neuropsychiatric symptoms after COVID-19 by contributing to priming; it elevates proinflammatory cytokines [173] and inflammation in the CNS [174]. Furthermore, increased microglial activation has been implicated in the cognitive decline linked to obesity [175].

\section{The Gastrointestinal System, the Gut Microbiome, and COVID-19}

\section{GI Symptoms in COVID-19}

A review of case reports and retrospective studies showed that gastrointestinal (GI) symptoms were present in acute COVID-19, with diarrhea being the most common, and noted that some patients presented with GI symptoms without respiratory symptoms and that severely ill patients were more likely to experience GI symptoms [176].

\section{Gut Dysbiosis, Inflammation, and Psychiatric Disorders in COVID-19}

Changes to the gut microbiome after SARS-CoV-2 infection seem to persist after virus clearance, and changes to the gut microbiome may play a significant role in chronic sequelae of COVID-19. Individuals with COVID-19 were found to have increased proportions of opportunistic fungal pathogens (i.e., Candida albicans, Candida auris, and Aspergillus flavus), at all-time points compared with controls, and two respiratory-associated fungal pathogens (i.e., A. flavus and Aspergillus niger) were detected in fecal samples from a subset of patients with COVID-19, even after clearance of SARS-CoV-2 from nasopharyngeal samples and resolution of respiratory symptoms [177]. Significant changes in fecal microbiomes of individuals with COVID-19, as compared to controls, have been noted, including more opportunistic pathogens and less beneficial commensals, both at the time of hospitalization and during hospitalization $[177,178 \bullet]$. Depleted symbionts and gut dysbiosis persisted even after clearance of SARS-CoV-2 (determined from throat swabs) and resolution of respiratory symptoms [178•]. Abundance of Coprobacillus, Clostridium ramosum, and Clostridium hathewayi correlated with COVID-19 severity [178•]. In addition, an inverse correlation between abundance of Faecalibacterium prausnitzii (an anti-inflammatory bacterium) and disease severity was observed [178•]. Bacteroides dorei, Bacteroides thetaiotaomicron, Bacteroides massiliensis, and Bacteroides ovatus, which have been shown to downregulate expression of ACE2 in the murine gut, correlated inversely with the amount of SARS-CoV-2 in fecal samples of hospitalized individuals [178 $\bullet$. Dysbiosis may also play a role in the severity of COVID-19, analogously to sepsis, through a disruption of the gut barrier integrity, which would lead to increased systemic inflammation and would allow SARSCoV-2 to translocate more easily [179].

SARS-CoV-2's effects on the microbiome may help better understand its neuroimmune effects and the pathophysiology of its neuropsychopathology, since the microbiome is able to contribute to the regulation of the immune system and interacts with the brain ("gut-brain axis"). Animal models have shown that during times of stress, the intestinal wall loses impermeability and bacteria can translocate from the gut to lymphoid organs [180]. Certain bacterial populations in the microbiome have been noted to affect the concentrations of regulatory T cells (Tregs) and Th17 cells [181], and thus potentially influence the balance of inflammation in the body. Treating mice with antibiotics has been shown to reduce the amount of proinflammatory cytokines that are produced (i.e., IL-6) in response to a stressor [182], thus potentially reducing cytokine storms in response to the SARS-CoV-2 virus. 
There is a link between the microbiome, inflammation, and psychiatric disorders [183-185]. Individuals with MDD were noted to have increased antibody titers against LPS derived from gram-negative enterobacteria compared to controls [186]. In maternally separated rats, administration of a probiotic reversed depressive-like behavior in the forced swim test (a model of depressive-like behavior) and reduced IL-6 concentrations (a proinflammatory marker) [187]. Likewise, experimental and clinical data suggest that an imbalanced gut microbiome in early life may create long-lasting effects (including long-lasting effects on immune signaling) that make individuals more susceptible to developing PTSD after a traumatic event [188] and thus, possibly, SARSCoV-2 PTSD triggering.

\section{Other CoVs and Neuropsychiatric Symptoms}

SARS-CoV-1 and MERS-CoV, similar to SARS-CoV-2, originated in bats and spread from human to human mainly through close contact with respiratory droplets [4]. SARSCoV-2 belongs to the same clade as MERS-CoV and SARS-CoV-1, possesses closely homologous sequences with SARS-CoV-1 [189], a similar lower airway-based pathogenesis with MERS-CoV and SARS-CoV-1 [190], and penetrates human cells using the same receptor as SARSCoV-1 [191].

MERS-CoV [192] and SARS-CoV-1 [193] have been associated with acute neuropsychiatric manifestations in both the PNS and CNS, similar to those that have been noted in SARS-CoV-2. Specifically, several SARS-CoV-1 patients developed large artery ischemic strokes [194]; about onethird of critically ill SARS-CoV-1 patients experienced deep vein thromboses (DVTs) or pulmonary embolisms (PEs), and an autopsy study revealed infarctions in multiple organs and microthrombi in the pulmonary and cardiac vessels, as well as widespread intravascular thrombi [193].

With much similarity between MERS-CoV and SARSCoV-1 with SARS-CoV-2, it is useful to consider long-term outcomes of human infection with the former two, to better understand potential long-term neuropsychiatric sequelae of COVID-19.

\section{Chronic Psychiatric Conditions After SARS-CoV-1 and MERS-CoV Infection}

A cohort study of SARS-CoV-1 survivors noted that more than half met criteria for at least one Diagnostic and Statistical Manual of Mental Disorders, fourth edition (DSM-IV) psychiatric disorder, and 30 months post-infection, onethird of patients were still experiencing psychiatric disease (25\% PTSD and 15\% a depressive disorder) [195]. A fouryear follow-up study of SARS-CoV-1 patients showed that
$40 \%$ of the respondents had active psychiatric illnesses, and $40.3 \%$ reported a chronic fatigue problem, with logistic regression analysis associating several social stressors (i.e., being a health care worker at the time of infection, being unemployed at follow-up, having a perception of social stigmatization, and having applied to the SARS survivors' fund) with an increased risk of psychiatric morbidities at the 4-year follow-up [196]. Some SARS-CoV-1 patients were noted to continue to experience fatigue, myalgia, weakness, depression, and non-restorative sleep with associated rapid eye movement (REM)-related apneas and hypopneas as well as electroencephalogram (EEG) abnormalities more than a year after the acute infection [197]. A meta-analysis noted that up to 6 months after discharge from the hospital survivors of SARS-CoV-1 and MERS most commonly experienced impaired DCLO and reduced exercise capacity (measured by the average distance walked in $6 \mathrm{~min}$ ), and about one-third of survivors were continuing to experience PTSD, anxiety, or depression 6 months after discharge [198]. Additionally, seropositivity for HCoV-NL63, a coronavirus causing mild upper respiratory infections, has been associated with a history of mood disorders [96], demonstrating that potential severity of coronavirus infection is not necessary for neuropsychological symptomatology or sequelae.

\section{Considerations for Treatment}

We realized that detailing a comprehensive approach to treatment of neuropsychiatric conditions in SARS-CoV-2 infection would be beyond the scope of the current review, and would have a short shelf life, because new approaches and treatments in COVID-19 are underway at a fast pace and would make our review obsolete. We would like to discuss elements in principle, which would be valid for the long run.

The first clinical step is to evaluate if the presentation is a component of sickness behavior or a psychiatric symptom. For instance, in the case of depression, while both conditions have similar behavioral and neurovegetative presentations, sickness without depression is characterized by a relatively intact sense of self: the past, the present, and the future. Another common aim is to rule out that psychiatric symptoms are actually side effects of medications used in treating COVID-19 and its associated complications. Then, it is very informative, when possible, to determine which acute and chronic symptoms of COVID-19 are due to the virus and which are due to the immune system's response to the virus. The implications for treatment are obvious, as immunomodulatory drugs and anti-viral approaches can help in one but may harm in others and may help at a particular time relative to infection and be detrimental at others. In parallel, CNS autoimmune targeting has to be investigated serologically in serum and CSF, and specifically treated, when 
present. Additionally, there are multiple targets to consider that may be helpful in increasing resilience to developing neuropsychiatric manifestations of COVID-19.

Therapeutic control and secondary prevention in conditions that lead to increased vulnerability to the virus (such as autoimmune disease, allergy, chronic infections and prevention of their exacerbations (e.g., herpes zoster) and diabetes), minimizing exposure to allergens, other pathogens (flu vaccination in time), pollutants, and traumatic brain injury, would be intended to reduce the priming of brain substrates. It is possible, before infections, that adherence to prescribed medications that are broadly used and have collateral immune modulatory effects, such as statins, will play a favorable role. Similarly, far from being demonstrated for COVID-19, treating severe vitamin D deficiency, known to result in immune dysregulation and impaired resistance to certain infections, may prove, through randomized clinical trials, to have favorable effects. Development of effective therapeutics against SARS-CoV-2 that can be administered intranasally may also come to be particularly important. A mouse model showed that a single-dose intranasal administration of an engineered IgM neutralizing antibody had prophylactic and therapeutic efficacy against SARS-CoV-2, including to several variants [199]. Intranasally administered therapeutics may prevent viral utilization of the neural pathway to the CNS, subsequent priming, or exploitation of vulnerabilities and may ultimately limit the development or exacerbation of neuropsychiatric disorders.

After infection, long-term treatment aims include controlled physical exercise, maintaining adequate sleep; preventing exacerbation of chronic infections, allergies, and autoimmune disease; and, reducing risk of concussions (e.g., falls); and, overreacting to stressors of everyday living (a target for counseling and psychotherapy). This may reduce the precipitation and perpetuation by these physical, biological, and psychological factors of low-grade immune activation and, thus, reduce the triggering of disproportionate responses from COVID-19-primed immune substrates, such as microglia. Psychotherapy's ability to influence inflammation has been well demonstrated. For instance, women treated with cognitive behavioral therapy (CBT) after experiencing their first episode of major depression showed a significant correlation between the decrease in IL-6 levels after treatment and remission rate [200].

As the microbiome has been shown to play a role in inflammation and mood disorders, and since the treatments affecting it are low risk, this is another treatment modality worth consideration. Ingestion of probiotic supplements has been shown to be a safe medical intervention, including for the young and elderly subjects, in an analysis of six randomized studies [201]. Probiotics, through modulation of both the innate and acquired immune systems, have shown efficacy in decreasing the severity of gastrointestinal and upper respiratory infections, including in healthy adults with high psychological stress and in the elderly [202]. Many of the positive effects from probiotic use are mediated through immune regulation, specifically influences on proinflammatory and anti-inflammatory cytokines [203]. A trial of an anti-inflammatory/immunoregulatory probiotic in Veterans with mild traumatic brain injury and PTSD showed a decrease in stress reactivity, as assessed by measurement of heart rate in response to the Trier Social Stress Test, and showed a decrease in CRP following 8 weeks of probiotic use, relative to baseline, that approached statistical significance [204]. This creates potential for probiotics to mitigate the effects of SARS-CoV-2 infection on priming the immune system or exacerbating preexisting vulnerabilities.

The term "psychobiotic" refers to a live organism that, when given in sufficient amounts, improves symptoms of psychiatric illness, and evidence suggests that psychobiotics can improve depression, anxiety, and chronic fatigue symptoms [184, 205]. The mechanism by which they impact the CNS involves the microbiome-gut-brain axis and signaling through the vagus nerve, spinal cord, endocrine, and immune systems [184, 205]. Some probiotics have anti-inflammatory properties that may work to counteract some of the priming of neuroinflammation [204]. Nonetheless, studies are still necessary to observe probiotic effectiveness in mitigating COVID-19 proximal (e.g., systemic inflammation) and distal outcomes (e.g., depressive symptoms).

\section{Future Research and Clinical Considerations}

Important future research considerations include understanding the modifiable neuroinvasive pathways, the role of the immune response in neuropsychiatric outcomes of COVID19 , heterogeneity of outcome, effects of specific psychiatric medications in post-COVID-19 syndromes, and biological mechanisms involved in age-related and racial disparities associated with COVID-19.

A better understanding of the role of inflammation in COVID-19 will be critical in mitigating morbidity and mortality in the short run, as well as improving our understanding of how viral pathogens contribute to neuropsychiatric disease. Understanding the biological basis of heterogeneity of outcome will also help us in this understanding and help identify vulnerable groups who stand to benefit even more from intervention. The role of commonly prescribed medications that have parallel SARS-CoV-2 access blocking or antiinflammatory effects will also be important. For example, a meta-analysis concluded that individuals taking angiotensinconverting enzyme inhibitors (ACEI) or angiotensin receptor blockers (ARBs) did not experience a worse outcome from COVID-19 and that these medications may play a protective 
role against the hyperinflammatory response associated with COVID-19, as noted in some studies by lower inflammatory markers in individuals with COVID-19 who were taking ACEI or ARBs [206]. Lastly, residual symptoms from SARS-CoV-2 infection, observed both in severe and nonsevere disease, are concerning. A better understanding of how immune interventions, exercise, neuromodulation, psychotherapy/counseling, and psychiatric medications can help alleviate these "long" COVID-19 symptoms will be vital to decreasing disability and returning individuals to full physical and mental health, as well as occupational, academic, and family functioning. Counseling will also be charged with a long shelf-life improvement by attending to reduced physical, cognitive, and interpersonal abilities imposed by SARS-CoV-2 infection and increasing the resilience as well as reducing overreacting to routine, day-to-day aggravations. This might help prevent psychological reactivity to inevitable hassles (i.e., triggers) of neuroimmunological substrates, which have been primed by infection, and are thus prone to immune overreaction, symptomatic exacerbation, and perpetuation of functional decline.

Brain imaging using PET tracers are necessary to identify activated microglia and astrocytes via the brain translocator protein (TSPO) binding [207] — with the goal of linking activation of microglia and astrocytes to demonstrated SARSCoV-2 infection (via RNA or molecular tests, or via CoV-2 serology) with vs. without new or exacerbated psychiatric symptoms. Brain TSPO binding previously has been found to be elevated in major depression episodes [208], although its link appears to be not exclusive with neuroinflammation, also including metabolic, oxidative stress, and energy production components [209]. Correlational analysis could relate the severity of new-onset psychiatric symptoms (e.g., depression, anxiety) to quantitative TSPO binding in regions of the brain relevant to SARS-CoV-2 penetration (e.g., olfactory bulbs), memory deficits (hippocampus), production of mood and anxiety symptoms (amygdala), and modulation of those symptoms (cingulate and prefrontal cortex) differentially in patients with vs. without history of SARS-CoV-2 positivity. A next step would be to test the central hypothesis that survivors of SARS-CoV-2 infection-those with higher TSPO binding-will show a higher mood, cognitive, and anxiety sensitivity to stress-by self-report and by specific experimental testing - than those with a lower TSPO binding. A following step would be to test if anti-inflammatory interventions, in particular those that cross the blood-brain barrier (BBB) vs. those that do not cross the BBB, will normalize the effect of the hypersensitivity to stressors, in parallel with TSPO binding. Broadly prescribed treatments that have an immunomodulatory effect, such as statins, could be used, as they have been shown to have major benefits in reducing severe outcomes in severe infections [210-217] with advantageous effects of statins emerging from both pretreatment
$[210,211,213,214,216,217]$ as well as continuation [211-213, 217] paradigms. Experimentally, statins have been shown to reduce microglia and astrocyte activation after controlled cortical impact injury [218]. Statins have also demonstrated benefit in autoimmune conditions, specifically in patients with MS, where simvastatin was shown to decrease the number and volume of Gd-enhancing lesions by $44 \%$ and $41 \%$, respectively [219].

Big data, and in particular machine learning applications, could also help with identifying the configuration of demographic, clinical (immune conditions, preexistent mental health conditions), laboratory, and pharmacological constellations that would lead to the strongest prediction of mental health symptoms occurrence, severity, and length, additionally identifying the characteristic individuals that are more likely to respond to preventative large-scale immune modifying interventions, such as the mentioned statin treatment, or perhaps the adequate treatment of vitamin $\mathrm{D}$ deficiency that has been associated with immune dysregulation [220, 221] and higher incidence of COVID-19 infection rate [222-225] and possibly severity [226-230] (although a causal link has not yet been proven).

\section{Conclusion}

Ongoing research is necessary to identify local and systemic interventions that may reduce the CNS invasive capability of SARS-CoV-2 and other coronaviruses [231], their immune activating and priming effects, and their induced predispositions to increased vulnerability to stress. As these effects are unlikely to be specific to SARS-CoV-2, this will deepen our understanding of the interactions between neurotropic microbes, the immune system, and the psychological stress in the pathophysiology of neuropsychiatric disorders. This may be a necessary step towards preventative efforts to reduce new onset, exacerbation, reactivation, and perpetuation of mental health conditions during pandemics with pan-organ microbial agents.

Acknowledgements The authors thank A. Dagdag and T. Stubborn for their excellent logistical assistance throughout this project. Components of this review have been presented and discussed by Dr. Postolache at the Session "COVID-19 and mental health: What do we know" at the 15 World Congress of Biological Psychiatry, June 28-39, 2021 (virtual). The results and interpretations provided represent opinions of the authors and not necessarily the official positions of the US Veterans Affairs Administration. The authors also thank Hira Mohyuddin, Conrad Mascarenhas and Alexandra Dagdag for their help with the proofing of the manuscript.

Author Contribution TTP, MEB, LAB, and JWS have conceptualized the content and general frame of the article. BNT and TTP have articulated the outline of the article, and CAL, DRB, MEB, OOO, LAB, and JWS have provided initial feedback. LAB, OOO, DRB, MEB, JWS, and TTP provided clinical expertise. LCK provided epidemiological 
and machine learning expertise. CAL, DRB, MEB, and TTP provided translational expertise. DRB and JWS provided neurological expertise, LAB, DRB, CAL, MEB, JWS, AJH, and TTP neuroimmunological expertise, LAB, OOO, and TTP psychotherapeutic/counseling expertise, LAB neuropsychological expertise, and OOO expertise in management of severe mental illness. BNT wrote the first draft of the manuscript and was also responsible for bibliographic management. BNT and TTP were responsible for graphics. TTP provided overall coordination between authors as well as individual mentorship to BNT. All authors provided critical intellectual input on successive drafts of the manuscript and approved its final version.

Funding This work is supported by MVM-CoRE and the Rocky Mountain MIRECC for Suicide Prevention, Aurora, Colorado. Dr. Postolache's contribution is further supported by a CSR\&D Merit Award (grant number 1 I01 CX001310-01). Dr. Michael E. Benros' work was supported by an unrestricted grant from The Lundbeck Foundation (grant number R268-2016-3925). Dr. Christopher A. Lowry was supported by the National Institute of Mental Health (grant number 1R21MH116263), the National Center for Complementary and Integrative Health (grant numbers R01AT010005 and R41AT011390), the Colorado Office of Economic Development and International Trade (OEDIT) Advanced Industries Accelerator Program (grant number CTGG1-2020-3064), and the Department of the Navy, Office of Naval Research Multidisciplinary University Research Initiative (MURI) Award (grant number N00014-15-1-2809).

\section{Compliance with Ethical Standards}

Conflict of Interest Dr. Christopher A. Lowry serves on the Scientific Advisory Board of Immodulon Therapeutics, Ltd., is Co-founder and Chief Scientific Officer of Mycobacteria Therapeutics Corporation, serves as an unpaid scientific consultant to Aurum Switzerland AG, and is a member of the faculty of the Integrative Psychiatry Institute. In the past 3 years, Dr. Kessler was a consultant for Datastat, Inc., Holmusk, RallyPoint Networks, Inc., and Sage Therapeutics. Dr. Kessler also has stock options in Mirah, PYM, and Roga Sciences. All other authors did not declare any conflict of interest.

Consent for Publication The authors have approved the final version of the manuscript.

Human and Animal Rights and Informed Consent All reported studies/ experiments with human or animal subjects performed by the authors have been previously published and complied with all applicable ethical standards (including the Helsinki declaration and its amendments, institutional/national research committee standards, and international/ national/institutional guidelines).

\section{References}

Papers of particular interest, published recently, have been highlighted as:

- Of importance

$\bullet$ Of major importance

1. National Center for Health Statistics (NCHS), Census Bureau. Mental Health - Household Pulse Survey - COVID-19. 2020. https://www.cdc.gov/nchs/covid19/pulse/mental-health.htm. Accessed November 27, 2020.
2. Wang Q, Xu R, Volkow ND. Increased risk of COVID-19 infection and mortality in people with mental disorders: analysis from electronic health records in the United States. World Psychiatr. 2021;20(1):124-30. https://doi.org/10.1002/wps.20806.

3. Nemani K, Li C, Olfson M, Blessing EM, Razavian N, Chen J, et al. Association of psychiatric disorders with mortality among patients with COVID-19. JAMA Psychiatr. 2021;78(4):380-6. https://doi.org/10.1001/jamapsychiatry.2020.4442.

4. Malik YA. Properties of coronavirus and SARS-CoV-2. Malays J Pathol. 2020;42(1):3-11.

5. Wang K, Chen W, Zhou Y-S, Lian J-Q, Zhang Z, Du P, et al. SARS-CoV-2 invades host cells via a novel route: CD147-spike protein. bioRxiv. 2020:2020.03.14.988345. https://doi.org/10. 1101/2020.03.14.988345

6.••Wrapp D, Wang N, Corbett KS, Goldsmith JA, Hsieh C-L, Abiona O, et al. Cryo-EM structure of the 2019-nCoV spike in the prefusion conformation. Science. 2020;367(6483):1260-3. https://doi.org/10.1126/science.abb2507. Describes particularities of SARS-CoV 2 leading to its stonger affinity for ACE2 facilitating cell entry.

7. Jansen JM, Gerlach T, Elbahesh H, Rimmelzwaan GF, Saletti G. Influenza virus-specific CD4+ and CD8+ T cell-mediated immunity induced by infection and vaccination. J Clin Virol. 2019;119:44-52. https://doi.org/10.1016/j.jcv.2019.08.009.

8. Diao B, Wang C, Tan Y, Chen X, Liu Y, Ning L, et al. Reduction and functional exhaustion of $\mathrm{T}$ cells in patients with coronavirus disease 2019 (COVID-19). Front Immunol. 2020;11:827. https:// doi.org/10.3389/fimmu.2020.00827.

9.•• Najjar S, Najjar A, Chong DJ, Pramanik BK, Kirsch C, Kuzniecky RI, et al. Central nervous system complications associated with SARS-CoV-2 infection: integrative concepts of pathophysiology and case reports. J Neuroinflammation. 2020;17(1):231. https:// doi.org/10.1186/s12974-020-01896-0. Details how the monocytes and macrophages are manipulated to serve the aims of transportation of the virus and its panorgan invasion.

10. Park MD. Macrophages: a Trojan horse in COVID-19? Nat Rev Immunol. 2020;20(6):351. https://doi.org/10.1038/s41577-020-0317-2.

11. McGonagle D, Sharif K, O'Regan A, Bridgewood C. The role of cytokines including interleukin-6 in COVID-19 induced pneumonia and macrophage activation syndrome-like disease. Autoimmun Rev. 2020;19(6):102537. https://doi.org/10.1016/j. autrev.2020.102537.

12. Zhang D, Guo R, Lei L, Liu H, Wang Y, Wang Y, et al. COVID-19 infection induces readily detectable morphologic and inflammation-related phenotypic changes in peripheral blood monocytes. J Leukoc Biol. 2020;109(1):13-22. https://doi.org/10.1002/jlb. 4hi0720-470r.

13. Conti P, Ronconi G, Caraffa A, Gallenga CE, Ross R, Frydas I, et al. Induction of pro-inflammatory cytokines (IL-1 and IL-6) and lung inflammation by Coronavirus-19 (COVI-19 or SARSCoV-2): anti-inflammatory strategies. J Biol Regul Homeost Agents. 2020;34(2):327-31. https://doi.org/10.23812/conti-e.

14. Ulrich H, Pillat MM. CD147 as a target for COVID-19 treatment: suggested effects of azithromycin and stem cell engagement. Stem Cell Rev Rep. 2020;16(3):434-40. https://doi.org/10.1007/ s12015-020-09976-7.

15. Gunn BM, Alter G. Modulating antibody functionality in infectious disease and vaccination. Trends Mol Med. 2016;22(11):96982. https://doi.org/10.1016/j.molmed.2016.09.002.

16. Murin CD, Wilson IA, Ward AB. Antibody responses to viral infections: a structural perspective across three different enveloped viruses. Nat Microbiol. 2019;4(5):734-47. https://doi.org/10.1038/ s41564-019-0392-y.

17. Zhao J, Yuan Q, Wang H, Liu W, Liao X, Su Y, et al. Antibody responses to SARS-CoV-2 in patients with novel coronavirus 
disease 2019. Clin Infect Dis. 2020;71(16):2027-34. https://doi. org/10.1093/cid/ciaa344.

18. Long QX, Liu BZ, Deng HJ, Wu GC, Deng K, Chen YK, et al. Antibody responses to SARS-CoV-2 in patients with COVID19. Nat Med. 2020;26(6):845-8. https://doi.org/10.1038/ s41591-020-0897-1.

19. Lou B, Li T-D, Zheng S-F, Su Y-Y, Li Z-Y, Liu W, et al. Serology characteristics of SARS-CoV-2 infection after exposure and postsymptom onset. Eur Respir J. 2020;56(2):2000763. https://doi.org/ 10.1183/13993003.00763-2020.

20. Gupta A, Madhavan MV, Sehgal K, Nair N, Mahajan S, Sehrawat TS, et al. Extrapulmonary manifestations of COVID-19. Nat Med. 2020;26(7):1017-32. https://doi.org/10.1038/s41591-020-0968-3.

21. Song E, Bartley CM, Chow RD, Ngo TT, Jiang R, Zamecnik $\mathrm{CR}$, et al. Divergent and self-reactive immune responses in the CNS of COVID-19 patients with neurological symptoms. Cell Rep Med. 2021;18;2(5):100288. https://doi.org/10.1016/j.xcrm. 2021.100288.

22. Li L-Q, Huang T, Wang Y-Q, Wang Z-P, Liang Y, Huang T-B, et al. COVID-19 patients' clinical characteristics, discharge rate, and fatality rate of meta-analysis. J Med Virol. 2020;92(6):57783. https://doi.org/10.1002/jmv.25757.

23. Del Sole F, Farcomeni A, Loffredo L, Carnevale R, Menichelli D, Vicario T, et al. Features of severe COVID-19: a systematic review and meta-analysis. Eur J Clin Invest. 2020;50(10):e13378. https://doi.org/10.1111/eci.13378.

24. Kragholm K, Andersen MP, Gerds TA, Butt JH, Østergaard L, Polcwiartek C, et al. Association between male sex and outcomes of coronavirus disease (Covid-19) - a Danish nationwide, registerbased study. Clin Infect Dis. 2019. https://doi.org/10.1093/cid/ ciaa924.

25. Scully EP, Haverfield J, Ursin RL, Tannenbaum C, Klein SL. Considering how biological sex impacts immune responses and COVID-19 outcomes. Nat Rev Immunol. 2020;20(7):442-7. https://doi.org/10.1038/s41577-020-0348-8.

26. Klein SL, Flanagan KL. Sex differences in immune responses. Nat Rev Immunol. 2016;16(10):626-38. https://doi.org/10.1038/ nri.2016.90.

27. Takahashi T, Ellingson MK, Wong P, Israelow B, Lucas C, Klein J, et al. Sex differences in immune responses that underlie COVID-19 disease outcomes. Nature. 2020;588(7837):315-20. https://doi.org/10.1038/s41586-020-2700-3.

28. Klein SL, Pekosz A, Park H-S, Ursin RL, Shapiro JR, Benner SE, et al. Sex, age, and hospitalization drive antibody responses in a COVID-19 convalescent plasma donor population. J Clin Investig. 2020;130(11):6141-50. https://doi.org/10.1172/JCI142004.

29.•• Desforges M, Le Coupanec A, Dubeau P, Bourgouin A, Lajoie L, Dube M, et al. Human coronaviruses and other respiratory viruses: underestimated opportunistic pathogens of the central nervous system? Viruses. 2019. https://doi.org/10.3390/v1201 0014. Important conceptual article about neuroinvasive capability of coronaviruses and other respiratory viruses, published simultanously with the onset of the pandemic.

30. Tonelli LH, Postolache TT. Airborne inflammatory factors: "from the nose to the brain." Front Biosci (Schol Ed). 2010;2:135-52. https://doi.org/10.2741/s52.

31. Mori I, Nishiyama Y, Yokochi T, Kimura Y. Olfactory transmission of neurotropic viruses. J Neurovirol. 2005;11(2):129-37. https://doi.org/10.1080/13550280590922793.

32. Pedras-Vasconcelos JA, Goucher D, Puig M, Tonelli LH, Wang $\mathrm{V}$, Ito $\mathrm{S}$, et al. $\mathrm{CpG}$ oligodeoxynucleotides protect newborn mice from a lethal challenge with the neurotropic Tacaribe arenavirus. J Immunol. 2006;176(8):4940-9. https://doi.org/10. 4049/jimmunol.176.8.4940.

33. Shankar V, Kao M, Hamir AN, Sheng H, Koprowski H, Dietzschold B. Kinetics of virus spread and changes in levels of several cytokine mRNAs in the brain after intranasal infection of rats with Borna disease virus. J Virol. 1992;66(2):992-8. https:// doi.org/10.1128/JVI.66.2.992-998.1992.

34. Mori I, Goshima F, Ito H, Koide N, Yoshida T, Yokochi T, et al. The vomeronasal chemosensory system as a route of neuroinvasion by herpes simplex virus. Virology. 2005;334(1):51-8. https://doi.org/ 10.1016/j.virol.2005.01.023.

35. Iwasaki T, Itamura S, Nishimura H, Sato Y, Tashiro M, Hashikawa $\mathrm{T}$, et al. Productive infection in the murine central nervous system with avian influenza virus A (H5N1) after intranasal inoculation. Acta Neuropathol. 2004;108(6):485-92. https://doi.org/10.1007/ s00401-004-0909-0.

36. Sauder CJ, Vandenburgh KM, Iskow RC, Malik T, Carbone KM, Rubin SA. Changes in mumps virus neurovirulence phenotype associated with quasispecies heterogeneity. Virology. 2006;350(1):4857. https://doi.org/10.1016/j.virol.2006.01.035.

37. Sellin CI, Davoust N, Guillaume V, Baas D, Belin MF, Buckland $\mathrm{R}$, et al. High pathogenicity of wild-type measles virus infection in CD150 (SLAM) transgenic mice. J Virol. 2006;80(13):6420 9. https://doi.org/10.1128/jvi.00209-06.

38. Meinhardt J, Radke J, Dittmayer C, Franz J, Thomas C, Mothes $\mathrm{R}$, et al. Olfactory transmucosal SARS-CoV-2 invasion as a port of central nervous system entry in individuals with COVID19. Nat Neurosci. 2020;24, 168-175. https://doi.org/10.1038/ s41593-020-00758-5.

39.•• Cantuti-Castelvetri L, Ojha R, Pedro LD, Djannatian M, Franz J, Kuivanen S, et al. Neuropilin-1 facilitates SARS-CoV-2 cell entry and infectivity. Science. 2020. https://doi.org/10.1126/ science.abd2985. Important article demonstrating an alternative pathway particularly relevant to the olfactory entry and systemic as well.

40. Dube M, Le Coupanec A, Wong AHM, Rini JM, Desforges M, Talbot PJ. Axonal transport enables neuron-to-neuron propagation of human coronavirus OC43. J Virol. 2018;92(17). https:// doi.org/10.1128/JVI.00404-18.

41. Jacomy H, St-Jean JR, Brison E, Marceau G, Desforges M, Talbot PJ. Mutations in the spike glycoprotein of human coronavirus OC43 modulate disease in $\mathrm{BALB} / \mathrm{c}$ mice from encephalitis to flaccid paralysis and demyelination. J Neurovirol. 2010;16(4):279-93. https://doi. org/10.3109/13550284.2010.497806.

42. Brison E, Jacomy H, Desforges M, Talbot PJ. Glutamate excitotoxicity is involved in the induction of paralysis in mice after infection by a human coronavirus with a single point mutation in its spike protein. J Virol. 2011;85(23):12464-73. https://doi. org/10.1128/JVI.05576-11.

43. Netland J, Meyerholz DK, Moore S, Cassell M, Perlman S. Severe acute respiratory syndrome coronavirus infection causes neuronal death in the absence of encephalitis in mice transgenic for human ACE2. J Virol. 2008;82(15):7264-75. https://doi.org/ 10.1128/jvi.00737-08.

44. Rhea EM, Logsdon AF, Hansen KM, Williams LM, Reed MJ, Baumann KK, et al. The $\mathrm{S} 1$ protein of SARS-CoV-2 crosses the blood-brain barrier in mice. Nat Neurosci. 2020;24, 68-378. https://doi.org/10.1038/s41593-020-00771-8.

45. Liu JM, Tan BH, Wu S, Gui Y, Suo JL, Li YC. Evidence of central nervous system infection and neuroinvasive routes, as well as neurological involvement, in the lethality of SARS-CoV-2 infection. J Med Virol. 2020. https://doi.org/10.1002/jmv.26570.

46. Moriguchi T, Harii N, Goto J, Harada D, Sugawara H, Takamino $\mathrm{J}$, et al. A first case of meningitis/encephalitis associated with SARS-coronavirus-2. Int J Infect Dis. 2020;94:55-8. https://doi. org/10.1016/j.ijid.2020.03.062.

47. Zhou L, Zhang M, Wang J, Gao J. Sars-Cov-2: Underestimated damage to nervous system. Travel Med Infect Dis. 2020;36:101642. https://doi.org/10.1016/j.tmaid.2020.101642. 
48. Domingues RB, Mendes-Correa MC, de Moura Leite FBV, Sabino EC, Salarini DZ, Claro I, et al. First case of SARS-COV-2 sequencing in cerebrospinal fluid of a patient with suspected demyelinating disease. J Neurol. 2020;267(11):3154-6. https://doi.org/10.1007/ s00415-020-09996-w.

49. Fadakar N, Ghaemmaghami S, Masoompour SM, Shirazi Yeganeh B, Akbari A, Hooshmandi S, et al. A first case of acute cerebellitis associated with coronavirus disease (COVID-19): a case report and literature review. The Cerebellum. 2020;19(6):911-4. https:// doi.org/10.1007/s12311-020-01177-9.

50. Westhoff TH, Seibert FS, Bauer F, Stervbo U, Anft M, Doevelaar AAN, et al. Allograft infiltration and meningoencephalitis by SARSCoV-2 in a pancreas-kidney transplant recipient. Am J Transplant. 2020;20(11):3216-20. https://doi.org/10.1111/ajt.16223.

51. Virhammar J, Kumlien E, Fällmar D, Frithiof R, Jackmann S, Sköld MK, et al. Acute necrotizing encephalopathy with SARS-CoV-2 RNA confirmed in cerebrospinal fluid. Neurology. 2020;95(10):4459. https://doi.org/10.1212/wnl.0000000000010250.

52. Khodamoradi Z, Hosseini SA, Gholampoor Saadi MH, Mehrabi Z, Sasani MR, Yaghoubi S. COVID-19 meningitis without pulmonary involvement with positive cerebrospinal fluid PCR. Eur J Neurol. 2020;27(12):2668-9. https://doi.org/10.1111/ene.14536.

53. Mardani M, Nadji SA, Sarhangipor KA, Sharifi-Razavi A, Baziboroun M. COVID-19 infection recurrence presenting with meningoencephalitis. New Microbes New Infect. 2020;37: 100732. https://doi.org/10.1016/j.nmni.2020.100732.

54. Al Saiegh F, Ghosh R, Leibold A, Avery MB, Schmidt RF, Theofanis T, et al. Status of SARS-CoV-2 in cerebrospinal fluid of patients with COVID-19 and stroke. J Neurol Neurosurg Psychiatr. 2020;91(8):846-8. https://doi.org/10.1136/ jnnp-2020-323522.

55. Neumann B, Schmidbauer ML, Dimitriadis K, Otto S, Knier B, Niesen W-D, et al. Cerebrospinal fluid findings in COVID-19 patients with neurological symptoms. J Neurol Sci. 2020;418:117090. https:// doi.org/10.1016/j.jns.2020.117090.

56. Puelles VG, Lutgehetmann M, Lindenmeyer MT, Sperhake JP, Wong MN, Allweiss L, et al. Multiorgan and renal tropism of SARS-CoV-2. N Engl J Med. 2020;383(6):590-2. https://doi. org/10.1056/NEJMc2011400.

57. Kremer S, Lersy F, Sèze Jd, Ferré J-C, Maamar A, Carsin-Nicol $\mathrm{B}$, et al. Brain MRI findings in severe COVID-19: a retrospective observational study. Radiology. 2020;297(2):E242-51. https:// doi.org/10.1148/radiol.2020202222.

58. Skok K, Stelzl E, Trauner M, Kessler HH, Lax SF. Post-mortem viral dynamics and tropism in COVID-19 patients in correlation with organ damage. Virchows Arch. 2020;478(2):343-353. https://doi.org/10.1007/s00428-020-02903-8.

59. Kantonen J, Mahzabin S, Mäyränpää MI, Tynninen O, Paetau A, Andersson N, et al. Neuropathologic features of four autopsied COVID-19 patients. Brain Pathol. 2020;30(6):1012-6. https:// doi.org/10.1111/bpa.12889.

60. Jensen MP, Le Quesne J, Officer-Jones L, Teodòsio A, Thaventhiran J, Ficken C, et al. Neuropathological findings in two patients with fatal COVID-19. Neuropathol Appl Neurobiol. 2021;5:87. https:// doi.org/10.1111/nan.12662.

61. Remmelink M, De Mendonça R, D'Haene N, De Clercq S, Verocq C, Lebrun L, et al. Unspecific post-mortem findings despite multiorgan viral spread in COVID-19 patients. Crit Care. 2020;24(1):495. https://doi.org/10.1186/s13054-020-03218-5.

62. Meinhardt J, Radke J, Dittmayer C, Mothes R, Franz J, Laue M, et al. Olfactory transmucosal SARS-CoV-2 invasion as port of central nervous system entry in individuals with COVID-19. Nat Neurosci.2021;24, 168-175. https://doi.org/10.1038/s41593-020-00758-5

63. Paniz-Mondolfi A, Bryce C, Grimes Z, Gordon RE, Reidy J, Lednicky J, et al. Central nervous system involvement by severe acute respiratory syndrome coronavirus-2 (SARS-CoV-2). J Med Virol. 2020;92(7):699-702. https://doi.org/10.1002/jmv.25915.

64. Al-Dalahmah O, Thakur KT, Nordvig AS, Prust ML, Roth W, Lignelli A, et al. Neuronophagia and microglial nodules in a SARSCoV-2 patient with cerebellar hemorrhage. Acta Neuropathol Commun. 2020;8(1):147. https://doi.org/10.1186/s40478-020-01024-2.

65. Solomon IH, Normandin E, Bhattacharyya S, Mukerji SS, Keller K, Ali AS, et al. Neuropathological features of Covid-19. N Engl J Med. 2020;383(10):989-92. https://doi.org/10.1056/NEJMc2019373.

66. Freij BJ, Gebara BM, Tariq R, Wang A-M, Gibson J, El-Wiher $\mathrm{N}$, et al. Fatal central nervous system co-infection with SARSCoV-2 and tuberculosis in a healthy child. BMC Pediatr. 2020;20(1):429. https://doi.org/10.1186/s12887-020-02308-1.

67. Hanley B, Naresh KN, Roufosse C, Nicholson AG, Weir J, Cooke GS, et al. Histopathological findings and viral tropism in UK patients with severe fatal COVID-19: a post-mortem study. The Lancet Microbe. 2020;1(6):e245-53. https://doi.org/10. 1016/S2666-5247(20)30115-4.

68. Bulfamante G, Chiumello D, Canevini MP, Priori A, Mazzanti M, Centanni S, et al. First ultrastructural autoptic findings of SARSCov-2 in olfactory pathways and brainstem. Minerva Anestesiol. 2020;86(6):678-9. https://doi.org/10.23736/s0375-9393.20.14772-2.

69. Song E, Zhang C, Israelow B, Lu-Culligan A, Prado AV, Skriabine $\mathrm{S}$, et al. Neuroinvasion of SARS-CoV-2 in human and mouse brain. J Exp Med. 2021;218 (3): e20202135. https://doi.org/10. 1101/2020.06.25.169946.

70. Lu S, Wei N, Jiang J, Wu L, Sheng J, Zhou J, et al. First report of manic-like symptoms in a COVID-19 patient with no previous history of a psychiatric disorder. J Affect Disord. 2020;277:33740. https://doi.org/10.1016/j.jad.2020.08.031.

71. Li C-W, Syue L-S, Tsai Y-S, Li M-C, Lo C-L, Tsai C-S, et al. Anosmia and olfactory tract neuropathy in a case of COVID-19. J Microbiol, Immunol Infect. 2020;54(1):93-96. https://doi.org/ 10.1016/j.jmii.2020.05.017.

72. Lin E, Lantos JE, Strauss SB, Phillips CD, Campion TR, Navi $\mathrm{BB}$, et al. Brain imaging of patients with COVID-19: findings at an academic institution during the height of the outbreak in New York City. Am J Neuroradiol. 2020;41(11):2001-8. https://doi.org/10.3174/ajnr.A6793.

73. Zheng J, Roy Wong L-Y, Li K, Verma AK, Ortiz M, WohlfordLenane C, et al. COVID-19 treatments and pathogenesis including anosmia in K18-hACE2 mice. Nature. 2021;589, 603-607. https://doi.org/10.1038/s41586-020-2943-z.

74. Fagre A, Lewis J, Eckley M, Zhan S, Rocha SM, Sexton NR, et al. SARS-CoV-2 infection, neuropathogenesis and transmission among deer mice: implications for reverse zoonosis to New World rodents. bioRxiv. 2020:2020. https://doi.org/10. 1101/2020.08.07.241810.

75. Muus C, Luecken MD, Eraslan G, Waghray A, Heimberg G, Sikkema $\mathrm{L}$, et al. Integrated analyses of single-cell atlases reveal age, gender, and smoking status associations with cell type-specific expression of mediators of SARS-CoV-2 viral entry and highlights inflammatory programs in putative target cells. bioRxiv. 2020:2020.04.19.049254. https://doi.org/ 10.1101/2020.04.19.049254.

76. Lamers MM, Beumer J, van der Vaart J, Knoops K, Puschhof J, Breugem TI, et al. SARS-CoV-2 productively infects human gut enterocytes. Science. 2020;369(6499):50-4. https://doi. org/10.1126/science.abc1669.

77. Bryce C, Grimes Z, Pujadas E, Ahuja S, Beasley MB, Albrecht R, et al. Pathophysiology of SARS-CoV-2: targeting of endothelial cells renders a complex disease with thrombotic microangiopathy and aberrant immune response. The Mount Sinai COVID-19 autopsy experience. MedRxiv. 2020. https://doi.org/10.1101/ 2020.05.18.20099960. 
78. Brann DH, Tsukahara T, Weinreb C, Lipovsek M, Van den Berge $\mathrm{K}$, Gong B, et al. Non-neuronal expression of SARS-CoV-2 entry genes in the olfactory system suggests mechanisms underlying COVID-19-associated anosmia. Sci Adv. 2020;6(31):5801. https://doi.org/10.1126/sciadv.abc5801.

79. Mesel-Lemoine M, Millet J, Vidalain PO, Law H, Vabret A, Lorin $\mathrm{V}$, et al. A human coronavirus responsible for the common cold massively kills dendritic cells but not monocytes. J Virol. 2012;86(14):7577-87. https://doi.org/10.1128/JVI.00269-12.

80. Song $\mathrm{X}, \mathrm{Hu} \mathrm{W}, \mathrm{Yu} \mathrm{H}, \mathrm{Zhao} \mathrm{L}$, Zhao Y, Zhao Y. High expression of angiotensin-converting enzyme-2 (ACE2) on tissue macrophages that may be targeted by virus SARS-CoV-2 in COVID19 patients. bioRxiv. 2020:2020.07.18.210120. https://doi.org/ 10.1101/2020.07.18.210120.

81. Gu J, Gong E, Zhang B, Zheng J, Gao Z, Zhong Y, et al. Multiple organ infection and the pathogenesis of SARS. J Exp Med. 2005;202(3):415-24. https://doi.org/10.1084/jem.20050828.

82. Nicholls JM, Butany J, Poon LL, Chan KH, Beh SL, Poutanen S, et al. Time course and cellular localization of SARS-CoV nucleoprotein and RNA in lungs from fatal cases of SARS. PLoS Med. 2006;3(2):e27. https://doi.org/10.1371/journal.pmed.0030027.

83. Collins AR. Human macrophages are susceptible to coronavirus OC43. Adv Exp Med Biol. 1998;440:635-9. https://doi.org/10. 1007/978-1-4615-5331-1_82.

84. Desforges M, Miletti TC, Gagnon M, Talbot PJ. Activation of human monocytes after infection by human coronavirus 229E. Virus Res. 2007;130(1-2):228-40. https://doi.org/10.1016/j. virusres.2007.06.016

85. Wentworth DE, Tresnan DB, Turner BC, Lerman IR, Bullis B, Hemmila EM, et al. Cells of human aminopeptidase N (CD13) transgenic mice are infected by human coronavirus-229E in vitro, but not in vivo. Virology. 2005;335(2):185-97. https://doi.org/10. 1016/j.virol.2005.02.023.

86. Boumaza A, Gay L, Mezouar S, Diallo AB, Michel M, Desnues $\mathrm{B}$, et al. Monocytes and Macrophages, Targets of Severe Acute Respiratory Syndrome Coronavirus 2: The Clue for Coronavirus Disease 2019 Immunoparalysis. J Infect Dis. 2021;224(3):395-406. https://doi.org/10.1093/infdis/jiab044. PMID: 33493287; PMCID: PMC7928817.

87. Arbour N, Day R, Newcombe J, Talbot PJ. Neuroinvasion by human respiratory coronaviruses. J Virol. 2000;74(19):8913-21. https://doi.org/10.1128/jvi.74.19.8913-8921.2000.

88. Arbour N, Côté G, Lachance C, Tardieu M, Cashman NR, Talbot PJ. Acute and persistent infection of human neural cell lines by human coronavirus OC43. J Virol. 1999;73(4):3338-50.

89. Arbour N, Ekandé S, Côté G, Lachance C, Chagnon F, Tardieu M, et al. Persistent infection of human oligodendrocytic and neuroglial cell lines by human coronavirus 229E. J Virol. 1999;73(4):3326-37.

90. Osipova ED, Semyachkina-Glushkovskaya OV, Morgun AV, Pisareva NV, Malinovskaya NA, Boitsova EB, et al. Gliotransmitters and cytokines in the control of blood-brain barrier permeability. Rev Neurosci. 2018;29(5):567-91. https://doi.org/10.1515/ revneuro-2017-0092.

91. Chen Y, Feng Z, Diao B, Wang R, Wang G, Wang C et al. The Novel Severe Acute Respiratory Syndrome Coronavirus 2 (SARS-CoV-2) Directly decimates human spleens and lymph nodes. medRxiv. 2020:2020.03.27.20045427. https://doi.org/10. 1101/2020.03.27.20045427.

92. Cui C, Xu P, Li G, Qiao Y, Han W, Geng C, et al. Vitamin D receptor activation regulates microglia polarization and oxidative stress in spontaneously hypertensive rats and angiotensin II-exposed microglial cells: Role of renin-angiotensin system. Redox Biol. 2019;26:101295. https://doi.org/10.1016/j.redox. 2019.101295.

93. Coutard B, Valle C, de Lamballerie X, Canard B, Seidah NG, Decroly E. The spike glycoprotein of the new coronavirus
2019-nCoV contains a furin-like cleavage site absent in CoV of the same clade. Antiviral Res. 2020;176:104742. https://doi.org/ 10.1016/j.antiviral.2020.104742.

94. Cheng J, Zhao Y, Xu G, Zhang K, Jia W, Sun Y, et al. The S2 subunit of QX-type infectious bronchitis coronavirus spike protein is an essential determinant of neurotropism. Viruses. 2019. https://doi.org/10.3390/v11100972.

95.• Rogers JP, Chesney E, Oliver D, Pollak TA, McGuire P, FusarPoli P, et al. Psychiatric and neuropsychiatric presentations associated with severe coronavirus infections: a systematic review and meta-analysis with comparison to the COVID-19 pandemic. The Lancet Psychiatr. 2020;7(7):611-627. https://doi. org/10.1016/S2215-0366(20)30203-0. A systematic review and metaanalysis of early psychiatric manifestations of severe COVID-19 infections

96. Okusaga O, Yolken RH, Langenberg P, Lapidus M, Arling TA, Dickerson FB, et al. Association of seropositivity for influenza and coronaviruses with history of mood disorders and suicide attempts. J Affect Disord. 2011;130(1-2):220-5. https://doi.org/ 10.1016/j.jad.2010.09.029.

97. Koralnik IJ, Tyler KL. COVID-19: a global threat to the nervous system. Ann Neurol. 2020;88(1):1-11. https://doi.org/10.1002/ ana. 25807.

98.•• Taquet M, Luciano S, Geddes JR, Harrison PJ. Bidirectional associations between COVID-19 and psychiatric disorder: retrospective cohort studies of 62354 COVID-19 cases in the USA. Lancet Psychiatr. 2020. https://doi.org/10.1016/S22150366(20)30462-4. Large sample analysis on bidirectional link between COVID-19 and psychiatric disorders.

99. Romero-Sánchez CM, Díaz-Maroto I, Fernández-Díaz E, Sánchez-Larsen Á, Layos-Romero A, García-García J, et al. Neurologic manifestations in hospitalized patients with COVID19: the ALBACOVID registry. Neurology. 2020;95(8):e106070. https://doi.org/10.1212/wnl.0000000000009937.

100. Mao L, Jin H, Wang M, Hu Y, Chen S, He Q, et al. Neurologic manifestations of hospitalized patients with coronavirus disease in Wuhan China. JAMA Neurol. 2019. https://doi.org/10.1001/ jamaneurol.2020.1127.

101. Lechien JR, Chiesa-Estomba CM, De Siati DR, Horoi M, Le Bon SD, Rodriguez A, et al. Olfactory and gustatory dysfunctions as a clinical presentation of mild-to-moderate forms of the coronavirus disease (COVID-19): a multicenter European study. Eur Arch Otorhinolaryngol. 2020;277(8):2251-61. https://doi. org/10.1007/s00405-020-05965-1.

102. Helms J, Kremer S, Merdji H, Clere-Jehl R, Schenck M, Kummerlen C, et al. Neurologic features in severe SARSCoV-2 infection. N Engl J Med. 2020;382(23):2268-70. https://doi.org/10.1056/NEJMc2008597.

103. Poyiadji N, Shahin G, Noujaim D, Stone M, Patel S, Griffith B. COVID-19-associated acute hemorrhagic necrotizing encephalopathy: imaging features. Radiology. 2020;296(2):E119-20. https://doi.org/10.1148/radiol.2020201187.

104. Sarma D, Bilello LA. A case report of acute transverse myelitis following novel coronavirus infection. Clin Pract Cases Emerg Med. 2020;4(3):321-3. https://doi.org/10.5811/cpcem.2020.5.47937.

105. Valiuddin H, Skwirsk B, Paz-Arabo P. Acute transverse myelitis associated with SARS-CoV-2: a case-report. Brain Behav Immun Health. 2020;5:100091. https://doi.org/10.1016/j.bbih.2020.100091.

106. AlKetbi R, AlNuaimi D, AlMulla M, AlTalai N, Samir M, Kumar N, et al. Acute myelitis as a neurological complication of Covid-19: a case report and MRI findings. Radiol Case Rep. 2020;15(9):1591-5. https://doi.org/10.1016/j.radcr.2020.06.001.

107. Munz M, Wessendorf S, Koretsis G, Tewald F, Baegi R, Krämer $\mathrm{S}$, et al. Acute transverse myelitis after COVID-19 pneumonia. J Neurol. 2020;267(8):2196-7. https://doi.org/10.1007/ s00415-020-09934-w. 
108. Sohal S, Mossammat M. COVID-19 presenting with seizures. IDCases. 2020;20:e00782. https://doi.org/10.1016/j.idcr.2020. e00782.

109. Dogra S, Jain R, Cao M, Bilaloglu S, Zagzag D, Hochman S, et al. Hemorrhagic stroke and anticoagulation in COVID-19. J Stroke Cerebrovasc Dis. 2020;29(8):104984. https://doi.org/10. 1016/j.jstrokecerebrovasdis.2020.104984.

110. Li Y, Li M, Wang M, Zhou Y, Chang J, Xian Y, et al. Acute cerebrovascular disease following COVID-19: a single center, retrospective, observational study. Stroke Vasc Neurol. 2020;5(3):279-284. https://doi.org/10.1136/svn-2020-000431.

111. Tan YK, Goh C, Leow AST, Tambyah PA, Ang A, Yap ES, et al. COVID-19 and ischemic stroke: a systematic review and meta-summary of the literature. J Thromb Thrombolysis. 2020;50(3):587-95. https://doi.org/10.1007/s11239-020-02228-y.

112. Oxley TJ, Mocco J, Majidi S, Kellner CP, Shoirah H, Singh IP, et al. Large-vessel stroke as a presenting feature of Covid-19 in the young. N Engl J Med. 2020;382(20):e60. https://doi.org/10. 1056/NEJMc2009787.

113. Brouwer MC, Ascione T, Pagliano P. Neurologic aspects of covid19: a concise review. Infez Med. 2020;28(suppl 1):42-5.

114. Han H, Yang L, Liu R, Liu F, Wu KL, Li J, et al. Prominent changes in blood coagulation of patients with SARS-CoV-2 infection. Clin Chem Lab Med. 2020;58(7):1116-20. https:// doi.org/10.1515/cclm-2020-0188.

115. Tang N, Li D, Wang X, Sun Z. Abnormal coagulation parameters are associated with poor prognosis in patients with novel coronavirus pneumonia. J Thromb Haemost. 2020;18(4):844-7. https://doi.org/10.1111/jth.14768.

116. Zhang Y, Xiao M, Zhang S, Xia P, Cao W, Jiang W, et al. Coagulopathy and antiphospholipid antibodies in patients with Covid-19. N Engl J Med. 2020;382(17):e38. https://doi.org/10. 1056/NEJMc2007575.

117. Varga Z, Flammer AJ, Steiger P, Haberecker M, Andermatt R, Zinkernagel AS, et al. Endothelial cell infection and endotheliitis in COVID-19. Lancet. 2020;395(10234):1417-8. https://doi.org/ 10.1016/s0140-6736(20)30937-5.

118. Guervilly C, Burtey S, Sabatier F, Cauchois R, Lano G, Abdili E, et al. Circulating endothelial cells as a marker of endothelial injury in severe COVID-19. J Infect Dis. 2020. https://doi.org/ 10.1093/infdis/jiaa528.

119. Kaseda ET, Levine AJ. Post-traumatic stress disorder: a differential diagnostic consideration for COVID-19 survivors. Clin Neuropsychol. 2020;34(7-8):1498-514. https://doi.org/10.1080/ 13854046.2020 .1811894$.

120. Zhu S, Gao Q, Yang L, Yang Y, Xia W, Cai X, et al. Prevalence and risk factors of disability and anxiety in a retrospective cohort of 432 survivors of coronavirus disease-2019 (Covid-19) from China. PLoS One. 2020;15(12):e0243883. https://doi.org/10. 1371/journal.pone.0243883.

121. Cai X, Hu X, Ekumi IO, Wang J, An Y, Li Z, et al. Psychological distress and its correlates among COVID-19 survivors during early convalescence across age groups. Am J Geriatr Psychiatr. 2020;28(10):1030-9. https://doi.org/10.1016/j.jagp.2020.07.003.

122.• Mazza MG, De Lorenzo R, Conte C, Poletti S, Vai B, Bollettini I, et al. Anxiety and depression in COVID-19 survivors: role of inflammatory and clinical predictors. Brain Behav Immun. 2020;89:594600. https://doi.org/10.1016/j.bbi.2020.07.037. An investigation on psychiatric syndromes and their predictors 1 month after hospitalization for COVID-19 in Milan, Italy.

123. Varatharaj A, Thomas N, Ellul MA, Davies NWS, Pollak TA, Tenorio EL, et al. Neurological and neuropsychiatric complications of COVID-19 in 153 patients: a UK-wide surveillance study. The lancet Psychiatry. 2020;7(10):875-82. https://doi.org/ 10.1016/S2215-0366(20)30287-X.
124. Smith CM, Komisar JR, Mourad A, Kincaid BR. COVID19-associated brief psychotic disorder. BMJ Case Rep. 2020;13(8):e236940. https://doi.org/10.1136/bcr-2020-236940.

125. Lim ST, Janaway B, Costello H, Trip A, Price G. Persistent psychotic symptoms following COVID-19 infection. BJPsych Open. 2020;6(5):e105. https://doi.org/10.1192/bjo.2020.76.

126. Ferrando SJ, Klepacz L, Lynch S, Tavakkoli M, Dornbush R, Baharani R, et al. COVID-19 psychosis: a potential new neuropsychiatric condition triggered by novel coronavirus infection and the inflammatory response? Psychosomatics. 2020;61(5):551-5. https://doi.org/10.1016/j.psym.2020.05.012.

127. Tenforde M, Kim S, Lindsell C, Rose E, Shapiro N, Files D, et al. Symptom duration and risk factors for delayed return to usual health among outpatients with COVID-19 in a multistate health care systems network - United States, March-June 2020. MMWR Morbidity and Mortality Weekly Report. 2020;69. https://doi.org/10.15585/mmwr.mm6930e1.

128. Zhao Y-M, Shang Y-M, Song W-B, Li Q-Q, Xie H, Xu Q-F, et al. Follow-up study of the pulmonary function and related physiological characteristics of COVID-19 survivors three months after recovery. EClinicalMedicine. 2020;25:100463. https://doi. org/10.1016/j.eclinm.2020.100463.

129. Davido B, Seang S, Tubiana R, de Truchis P. Post-COVID-19 chronic symptoms: a postinfectious entity? Clin Microbiol Infect. 2020;26(11):1448-1449. https://doi.org/10.1016/j.cmi.2020.07.028.

130. Carfì A, Bernabei R, Landi F. Group ftGAC-P-ACS. persistent symptoms in patients after acute COVID-19. JAMA. 2020;324(6):603-5. https://doi.org/10.1001/jama.2020.12603.

131. Carfì A, Bernabei R, Landi F. Persistent symptoms in patients after acute COVID-19. JAMA. 2020;324(6):603-5. https://doi.org/10. 1001/jama.2020.12603.

132. Yan CH, Faraji F, Prajapati DP, Boone CE, DeConde AS. Association of chemosensory dysfunction and COVID-19 in patients presenting with influenza-like symptoms. Int Forum Allergy Rhinol. 2020;10(7):806-13. https://doi.org/10.1002/alr.22579.

133. Bonfils P, Avan P, Faulcon P, Malinvaud D. Distorted odorant perception: analysis of a series of 56 patients with parosmia. Arch Otolaryngol-Head Neck Surg. 2005;131(2):107-12. https:// doi.org/10.1001/archotol.131.2.107.

134.• Addison AB, Wong B, Ahmed T, Macchi A, Konstantinidis I, Huart C, et al. Clinical olfactory working group consensus statement on the treatment of post infectious olfactory dysfunction. $\mathrm{J}$ Allergy Clin Immunol. 2021;147(5):1704-1719. https://doi.org/ 10.1016/j.jaci.2020.12.641. Important article considering the frequncy of anosmia, hyposmia, and parosmia post COVID-19.

135. Halpin SJ, McIvor C, Whyatt G, Adams A, Harvey O, McLean $\mathrm{L}$, et al. Postdischarge symptoms and rehabilitation needs in survivors of COVID-19 infect. J Med Virol. 2021;93(2):1013-1022. https://doi.org/10.1002/jmv.26368.

136.• Huang C, Huang L, Wang Y, Li X, Ren L, Gu X, et al. 6-month consequences of COVID-19 in patients discharged from hospital: a cohort study. Lancet. 2021;397(10270):220 32. https://doi.org/10.1016/s0140-6736(20)32656-8. A large 6-month cohort study reporting high prevalence of fatigue, anxiety, and depression long after the resolution of the initial symptoms of COVID-19.

137. Del Rio R, Marcus NJ, Inestrosa NC. Potential Role of autonomic dysfunction in Covid-19 morbidity and mortality. Front Physiol. 2020;11:561749. https://doi.org/10.3389/fphys.2020. 561749. Article describing the potential role of autonomic dysfunction in COVID-19.

138. Dani M, Dirksen A, Taraborrelli P, Torocastro M, Panagopoulos D, Sutton R, et al. Autonomic dysfunction in 'long COVID': rationale, physiology and management strategies. Clin Med (Lond). 2020. https://doi.org/10.7861/clinmed.2020-0896. As 
above, this article also includes physiology-based management strategies.

139. Miglis MG, Prieto T, Shaik R, Muppidi S, Sinn DI, Jaradeh S. A case report of postural tachycardia syndrome after COVID19. Clin Auton Res. 2020;30(5):449-51. https://doi.org/10.1007/ s10286-020-00727-9.

140. Ghosh R, Roy D, Sengupta S, Benito-León J. Autonomic dysfunction heralding acute motor axonal neuropathy in COVID-19. J Neurovirol. 2020;26(6):964-6. https://doi.org/10.1007/s13365-020-00908-2.

141. Eshak N, Abdelnabi M, Ball S, Elgwairi E, Creed K, Test V, et al. Dysautonomia: an overlooked neurological manifestation in a critically ill COVID-19 patient. Am J Med Sci. 2020;360(4):427-9. https://doi.org/10.1016/j.amjms.2020.07.022.

142. Steardo L Jr, Steardo L, Verkhratsky A. Psychiatric face of COVID-19. Transl Psychiatr. 2020;10(1):261. https://doi.org/10. 1038/s41398-020-00949-5.

143. Sotzny F, Blanco J, Capelli E, Castro-Marrero J, Steiner S, Murovska M, et al. Myalgic encephalomyelitis/chronic fatigue syndrome - evidence for an autoimmune disease. Autoimmun Rev. 2018;17(6):601-9. https://doi.org/10.1016/j.autrev.2018.01.009.

144. Toubasi AA, AbuAnzeh RB, Tawileh HBA, Aldebei RH, Alryalat SAS. A meta-analysis: the mortality and severity of COVID19 among patients with mental disorders. Psychiatry Res. 2021;299:113856. https://doi.org/10.1016/j.psychres.2021.113856.

145. Egede J, Campbell JA, Walker RJ, Garacci E, Dawson AZ, Egede LE. Relationship between physical and mental health comorbidities and COVID-19 positivity, hospitalization, and mortality. J Affect Disord. 2021;283:94-100. https://doi.org/10.1016/j.jad.2021.01.048.

146. Egede C, Dawson AZ, Walker RJ, Garacci E, Campbell JA, Egede LE. Relationship between mental health diagnoses and COVID-19 test positivity, hospitalization, and mortality in Southeast Wisconsin. Psychol Med. 2021. https://doi.org/10.1017/S0033291721002312.

147. Li L, Li F, Fortunati F, Krystal JH. Association of a prior psychiatric diagnosis with mortality among hospitalized patients with coronavirus disease 2019 (COVID-19) Infection. JAMA Netw Open. 2020;3(9):e2023282. https://doi.org/10.1001/jamanetworkopen. 2020.23282

148. Barcella CA, Polcwiartek C, Mohr GH, Hodges G, Søndergaard $\mathrm{K}$, Niels Bang C, et al. Severe mental illness is associated with increased mortality and severe course of COVID-19. Acta Psychiatr Scand. 2021;144(1):82-91. https://doi.org/10.1111/acps. 13309.

149. Maripuu M, Bendix M, Öhlund L, Widerström M, Werneke U. Death associated with coronavirus (COVID-19) infection in individuals with severe mental disorders in Sweden during the early months of the outbreak-an exploratory cross-sectional analysis of a population-based register study. Front Psychiatr. 2020;11:609579. https://doi.org/10.3389/fpsyt.2020.609579.

150. Norden DM, Muccigrosso MM, Godbout JP. Microglial priming and enhanced reactivity to secondary insult in aging, and traumatic CNS injury, and neurodegenerative disease. Neuropharmacology. 2015;96:29-41. https://doi.org/10.1016/j.neuropharm.2014.10.028.

151.• Fonken LK, Frank MG, Gaudet AD, Maier SF. Stress and aging act through common mechanisms to elicit neuroinflammatory priming. Brain Behav Immun. 2018;73:133-48. https://doi.org/ 10.1016/j.bbi.2018.07.012. Conceptual article that discusses the neuroinflammatory priming by stress and aging, affirming a psychological and a demographic factor that have similar biological effects to infectious, autoimmune, and traumatic factors.

152. Niraula A, Sheridan JF, Godbout JP. Microglia priming with aging and stress. Neuropsychopharmacology. 2017;42(1):31833. https://doi.org/10.1038/npp.2016.185.

153. Tay TL, Béchade C, D’Andrea I, St-Pierre M-K, Henry MS, Roumier A, et al. Microglia gone rogue: impacts on psychiatric disorders across the lifespan. Front Mol Neurosci. 2018. https://doi.org/10.3389/fnmol.2017.00421.
154. Haley MJ, Brough D, Quintin J, Allan SM. Microglial priming as trained immunity in the brain. Neuroscience. 2019;405:4754. https://doi.org/10.1016/j.neuroscience.2017.12.039.

155. Glaser R, Kiecolt-Glaser JK. Stress-induced immune dysfunction: implications for health. Nat Rev Immunol. 2005;5(3):24351. https://doi.org/10.1038/nri1571.

156. Miller GE, Chen E, Sze J, Marin T, Arevalo JMG, Doll R, et al. A functional genomic fingerprint of chronic stress in humans: blunted glucocorticoid and increased NF-kappaB signaling. Biol Psychiatr. 2008;64(4):266-72. https://doi.org/ 10.1016/j.biopsych.2008.03.017.

157. Wohleb ES, Powell ND, Godbout JP, Sheridan JF. Stress-induced recruitment of bone marrow-derived monocytes to the brain promotes anxiety-like behavior. J Neurosci. 2013;33(34):13820-33. https://doi.org/10.1523/JNEUROSCI.1671-13.2013.

158. Dubey S, Biswas P, Ghosh R, Chatterjee S, Dubey MJ, Chatterjee S, et al. Psychosocial impact of COVID-19. Diabetes Metab Syndr. 2020;14(5):779-88. https://doi.org/10.1016/j.dsx.2020.05.035.

159. Vanherwegen A-S, Gysemans C, Mathieu C. Regulation of immune function by vitamin $\mathrm{D}$ and its use in diseases of immunity. Endocrinol Metab Clin North Am. 2017;46(4):1061-94. https://doi.org/10.1016/j.ecl.2017.07.010.

160. Getts DR, Chastain EML, Terry RL, Miller SD. Virus infection, antiviral immunity, and autoimmunity. Immunol Rev. 2013;255(1):197209. https://doi.org/10.1111/imr.12091.

161. Lynch DR, Rattelle A, Dong YN, Roslin K, Gleichman AJ, Panzer JA. Anti-NMDA receptor encephalitis: clinical features and basic mechanisms. Adv Pharmacol. 2018;82:235-60. https://doi.org/10.1016/bs.apha.2017.08.005.

162. Dalmau J, Armangué T, Planagumà J, Radosevic M, Mannara F, Leypoldt F, et al. An update on anti-NMDA receptor encephalitis for neurologists and psychiatrists: mechanisms and models. Lancet Neurol. 2019;18(11):1045-57. https://doi.org/10.1016/ S1474-4422(19)30244-3.

163. Williams TJ, Benavides DR, Patrice KA, Dalmau JO, de Ávila AL, Le DT, et al. Association of autoimmune encephalitis with combined immune checkpoint inhibitor treatment for metastatic cancer. JAMA Neurol. 2016;73(8):928-33. https://doi. org/10.1001/jamaneurol.2016.1399.

164. Höftberger R, Lassmann H. Acute disseminated encephalomyelitis and acute hemorrhagic leukoencephalomyelitis. Infections of the Central Nervous System. 2020. p. 251-7.

165. Woodruff MC, Ramonell RP, Lee FE-H, Sanz I. Broadlytargeted autoreactivity is common in severe SARS-CoV-2 Infection. medRxiv. 2020:2020. https://doi.org/10.1101/2020.10.21. 20216192

166. Kang SJ, Jung SI. Age-related morbidity and mortality among patients with COVID-19. Infect Chemother. 2020;52(2):15464. https://doi.org/10.3947/ic.2020.52.2.154.

167. Barrientos RM, Frank MG, Hein AM, Higgins EA, Watkins LR, Rudy JW, et al. Time course of hippocampal IL- $1 \beta$ and memory consolidation impairments in aging rats following peripheral infection. Brain Behav Immun. 2009;23(1):46-54. https://doi. org/10.1016/j.bbi.2008.07.002.

168. Chen J, Buchanan JB, Sparkman NL, Godbout JP, Freund GG, Johnson RW. Neuroinflammation and disruption in working memory in aged mice after acute stimulation of the peripheral innate immune system. Brain Behav Immun. 2008;22(3):30111. https://doi.org/10.1016/j.bbi.2007.08.014.

169. Godbout JP, Chen J, Abraham J, Richwine AF, Berg BM, Kelley $\mathrm{KW}$, et al. Exaggerated neuroinflammation and sickness behavior in aged mice after activation of the peripheral innate immune system. FASEB J. 2005;19(10):1329-31. https://doi.org/10. 1096/fj.05-3776fje.

170. Huang Y, Henry CJ, Dantzer R, Johnson RW, Godbout JP. Exaggerated sickness behavior and brain proinflammatory cytokine 
expression in aged mice in response to intracerebroventricular lipopolysaccharide. Neurobiol Aging. 2008;29(11):1744-53. https://doi.org/10.1016/j.neurobiolaging.2007.04.012.

171. Frank MG, Barrientos RM, Watkins LR, Maier SF. Aging sensitizes rapidly isolated hippocampal microglia to LPS ex vivo. J Neuroimmunol. 2010;226(1):181-4. https://doi.org/10.1016/j. jneuroim.2010.05.022.

172. Yang J, Hu J, Zhu C. Obesity aggravates COVID-19: a systematic review and meta-analysis. J Med Virol. 2020;93(1):257-261. doi:https://doi.org/10.1002/jmv.26237. Systematic review and metaanalysis of COVID-19 with importance for prognosis, for clinical approaches, for prevention, and for methodological considerations, i.e., adjustments for BMI and obesity status in those frequent instances when there is potential for confounding.

173. Schmidt FM, Weschenfelder J, Sander C, Minkwitz J, Thormann $\mathrm{J}$, Chittka T, et al. Inflammatory cytokines in general and central obesity and modulating effects of physical activity. PLoS One. 2015;10(3):e0121971. https://doi.org/10.1371/journal.pone. 0121971.

174. Jais A, Brüning JC. Hypothalamic inflammation in obesity and metabolic disease. J Clin Invest. 2017;127(1):24-32. https://doi. org/10.1172/jci88878.

175. Cope EC, LaMarca EA, Monari PK, Olson LB, Martinez S, Zych $\mathrm{AD}$, et al. Microglia play an active role in obesity-associated cognitive decline. J Neurosci. 2018;38(41):8889-904. https:// doi.org/10.1523/jneurosci.0789-18.2018.

176. Tian Y, Rong L, Nian W, He Y. Review article: gastrointestinal features in COVID-19 and the possibility of faecal transmission. Aliment Pharmacol Ther. 2020;51(9):843-51. https://doi.org/10. 1111/apt.15731.

177. Zuo T, Zhan H, Zhang F, Liu Q, Tso EYK, Lui GCY, et al. Alterations in fecal fungal microbiome of patients with COVID19 during time of hospitalization until discharge. Gastroenterology. 2020;159(4):1302-1310.e5. https://doi.org/10.1053/j.gastro. 2020.06 .048

178. Zuo T, Zhang F, Lui GCY, Yeoh YK, Li AYL, Zhan H, et al. Alterations in gut microbiota of patients with COVID-19 during time of hospitalization. Gastroenterology. 2020;159(3):944-955. e8. https://doi.org/10.1053/j.gastro.2020.05. Article discussing dysbiosis in COVID-19.

179. Aktas B, Aslim B. Gut-lung axis and dysbiosis in COVID19. Turk J Biol. 2020;44(3):265-72. https://doi.org/10.3906/ biy-2005-102.

180. Bailey MT, Engler H, Sheridan JF. Stress induces the translocation of cutaneous and gastrointestinal microflora to secondary lymphoid organs of C57BL/6 mice. J Neuroimmunol. 2006;171(1-2):29-37. https://doi.org/10.1016/j.jneuroim.2005.09.008.

181. Haroon E, Raison CL, Miller AH. Psychoneuroimmunology meets neuropsychopharmacology: translational implications of the impact of inflammation on behavior. Neuropsychopharmacology. 2012;37(1):137-62. https://doi.org/10.1038/npp.2011.205.

182. Bailey MT, Dowd SE, Galley JD, Hufnagle AR, Allen RG, Lyte M. Exposure to a social stressor alters the structure of the intestinal microbiota: implications for stressor-induced immunomodulation. Brain Behav Immun. 2011;25(3):397-407. https://doi. org/10.1016/j.bbi.2010.10.023.

183. Valles-Colomer M, Falony G, Darzi Y, Tigchelaar EF, Wang J, Tito RY, et al. The neuroactive potential of the human gut microbiota in quality of life and depression. Nat Microbiol. 2019;4(4):623-32. https://doi.org/10.1038/s41564-018-0337-x.

184. Flux MC, Lowry CA. Finding intestinal fortitude: integrating the microbiome into a holistic view of depression mechanisms, treatment, and resilience. Neurobiol Dis. 2020;135:104578. https:// doi.org/10.1016/j.nbd.2019.104578.
185. Yang J, Zheng P, Li Y, Wu J, Tan X, Zhou J, et al. Landscapes of bacterial and metabolic signatures and their interaction in major depressive disorders. Sci Adv. 2020;6(49):eaba555. https://doi. org/10.1126/sciadv.aba8555.

186. Maes M, Kubera M, Leunis JC. The gut-brain barrier in major depression: intestinal mucosal dysfunction with an increased translocation of LPS from gram negative enterobacteria (leaky gut) plays a role in the inflammatory pathophysiology of depression. Neuro Endocrinol Lett. 2008;29(1):117-24.

187. Desbonnet L, Garrett L, Clarke G, Kiely B, Cryan JF, Dinan TG. Effects of the probiotic Bifidobacterium infantis in the maternal separation model of depression. Neuroscience. 2010;170(4):1179-88. https://doi.org/10.1016/j.neuroscience. 2010.08.005

188. Leclercq S, Forsythe P, Bienenstock J. Posttraumatic stress disorder: does the gut microbiome hold the key? Can J Psychiatry. 2016;61(4):204-13. https://doi.org/10.1177/0706743716635535.

189. Yu F, Du L, Ojcius DM, Pan C, Jiang S. Measures for diagnosing and treating infections by a novel coronavirus responsible for a pneumonia outbreak originating in Wuhan. China Microbes Infect. 2020;22(2):74-9. https://doi.org/10.1016/j.micinf.2020.01.003.

190. Song Z, Xu Y, Bao L, Zhang L, Yu P, Qu Y, et al. From SARS to MERS, thrusting coronaviruses into the spotlight. Viruses. 2019;11(1):874. https://doi.org/10.3390/v11010059.

191. Lu R, Zhao X, Li J, Niu P, Yang B, Wu H, et al. Genomic characterisation and epidemiology of 2019 novel coronavirus: implications for virus origins and receptor binding. Lancet. 2020;395(10224):56574. https://doi.org/10.1016/S0140-6736(20)30251-8.

192. Arabi YM, Harthi A, Hussein J, Bouchama A, Johani S, Hajeer $\mathrm{AH}$, et al. Severe neurologic syndrome associated with Middle East respiratory syndrome corona virus (MERS-CoV). Infection. 2015;43(4):495-501. https://doi.org/10.1007/s15010-015-0720-y.

193. Tsai LK, Hsieh ST, Chang YC. Neurological manifestations in severe acute respiratory syndrome. Acta Neurol Taiwan. 2005;14(3):113-9.

194. Umapathi T, Kor AC, Venketasubramanian N, Lim CC, Pang $\mathrm{BC}$, Yeo TT, et al. Large artery ischaemic stroke in severe acute respiratory syndrome (SARS). J Neurol. 2004;251(10):1227-31. https://doi.org/10.1007/s00415-004-0519-8.

195. Mak IWC, Chu CM, Pan PC, Yiu MGC, Chan VL. Long-term psychiatric morbidities among SARS survivors. Gen Hosp Psychiatry. 2009;31(4):318-26. https://doi.org/10.1016/j. genhosppsych.2009.03.001.

196. Lam MH-B, Wing Y-K, Yu MW-M, Leung C-M, Ma RCW, Kong APS, et al. Mental morbidities and chronic fatigue in severe acute respiratory syndrome survivors: long-term follow-up. Arch Intern Med. 2009;169(22):2142-7. https://doi.org/10.1001/archinternmed. 2009.384.

197. Moldofsky H, Patcai J. Chronic widespread musculoskeletal pain, fatigue, depression and disordered sleep in chronic post-SARS syndrome; a case-controlled study. BMC Neurol. 2011;11:37. https://doi.org/10.1186/1471-2377-11-37.

198. Ahmed H, Patel K, Greenwood DC, Halpin S, Lewthwaite P, Salawu A, et al. Long-term clinical outcomes in survivors of severe acute respiratory syndrome and Middle East respiratory syndrome coronavirus outbreaks after hospitalisation or ICU admission: a systematic review and meta -analysis. J Rehabil Med. 2020;52(5):jrm00063. https://doi.org/10.2340/16501977-2694.

199. Ku Z, Xie X, Hinton PR, Liu X, Ye X, Muruato AE, et al. Nasal delivery of an IgM offers broad protection from SARS-CoV-2 variants. Nature. 2021;595:718-723. https://doi.org/10.1038/ s41586-021-03673-2.

200. Gazal M, Souza LD, Fucolo BA, Wiener CD, Silva RA, Pinheiro RT, et al. The impact of cognitive behavioral therapy on IL-6 levels in unmedicated women experiencing the first episode of 
depression: a pilot study. Psychiatry Res. 2013;209(3):742-5. https://doi.org/10.1016/j.psychres.2013.03.002.

201. Tapiovaara L, Lehtoranta L, Poussa T, Mäkivuokko H, Korpela R, Pitkäranta A. Absence of adverse events in healthy individuals using probiotics-analysis of six randomised studies by one study group. Beneficial Microbes. 2016;7(2):161-9. https://doi. org/10.3920/bm2015.0096.

202. Kanauchi O, Andoh A, AbuBakar S, Yamamoto N. Probiotics and paraprobiotics in viral infection: clinical application and effects on the innate and acquired immune systems. Curr Pharm Des. 2018;24(6):710-7. https://doi.org/10.2174/ 1381612824666180116163411.

203. Isolauri E, Sütas Y, Kankaanpää P, Arvilommi H, Salminen S. Probiotics: effects on immunity. Am J Clin Nutr. 2001;73(2 Suppl):444s-s450. https://doi.org/10.1093/ajcn/73.2.444s.

204. Brenner LA, Forster JE, Stearns-Yoder KA, Stamper CE, Hoisington AJ, Brostow DP, et al. Evaluation of an immunomodulatory probiotic intervention for veterans with cooccurring mild traumatic brain injury and posttraumatic stress disorder: a pilot study. Front Neurol. 2020;11(1015):841. https://doi.org/10.3389/fneur.2020.01015.

205. Dinan TG, Stanton C, Cryan JF. Psychobiotics: a novel class of psychotropic. Biol Psychiatry. 2013;74(10):720-6. https://doi. org/10.1016/j.biopsych.2013.05.001.

206. Naveed H, Elshafeey A, Al-Ali D, Janjua E, Nauman A, Kawas $\mathrm{H}$, et al. The interplay between the immune system, the reninangiotensin-aldosterone system (RAAS), and RAAS inhibitors may modulate the outcome of COVID-19: a systematic review. J Clin Pharmacol. 2021. https://doi.org/10.1002/jcph.1852.

207. Chechneva OV, Deng W. Mitochondrial translocator protein (TSPO), astrocytes and neuroinflammation. Neural Regen Res. 2016;11(7):1056-7. https://doi.org/10.4103/1673-5374.187027.

208. Setiawan E, Wilson AA, Mizrahi R, Rusjan PM, Miler L, Rajkowska G, et al. Role of translocator protein density, a marker of neuroinflammation, in the brain during major depressive episodes. JAMA Psychiatr. 2015;72(3):268-75. https://doi.org/10. 1001/jamapsychiatry.2014.2427.

209. Notter T, Coughlin JM, Sawa A, Meyer U. Reconceptualization of translocator protein as a biomarker of neuroinflammation in psychiatry. Mol Psychiatr. 2018;23(1):36-47. https://doi.org/10. 1038/mp.2017.232.

210. Yang TF, Chu H, Ou SM, Li SY, Chen YT, Shih CJ, et al. Effect of statin therapy on mortality in patients with infective endocarditis. Am J Cardiol. 2014;114(1):94-9. https://doi.org/10.1016/j. amjcard.2014.03.064.

211. Caffrey AR, Timbrook TT, Noh E, Sakoulas G, Opal SM, Nizet V, et al. Evidence to support continuation of statin therapy in patients with Staphylococcus aureus bacteremia. Antimicrob Agents Chemother. 2017;61(3):84. https://doi.org/10.1128/AAC.02228-16.

212. Hu SY, Hsieh MS, Lin TC, Liao SH, Hsieh VC, Chiang JH, et al. Statins improve the long-term prognosis in patients who have survived sepsis: a nationwide cohort study in Taiwan (STROBE complaint). Medicine (Baltimore). 2019;98(17):e15253. https:// doi.org/10.1097/MD.0000000000015253.

213. Hung TH, Tsai CC, Lee HF. Statin use in cirrhotic patients with infectious diseases: a population-based study. PLoS One. 2019;14(4):e0215839. https://doi.org/10.1371/journal.pone.0215839.

214. Cheng CY, Kung CT, Chen FC, Cheng HH, Tsai TC, Hsiao SY, et al. Impact of prior statin use on mortality in patients with type 2 diabetes mellitus and bloodstream infection. J Int Med Res. 2019;47(8):3636-47. https://doi.org/10.1177/0300060519856137.

215. Sapey E, Patel JM, Greenwood H, Walton GM, Grudzinska F, Parekh D, et al. Simvastatin improves neutrophil function and clinical outcomes in pneumonia. a pilot randomized controlled clinical trial. Am J Respir Crit Care Med. 2019;200(10):128293. https://doi.org/10.1164/rccm.201812-2328OC.
216. Alzahrani T, Liappis AP, Baddour LM, Karasik PE. Statin use and the risk of cardiovascular implantable electronic device infection: a cohort study in a veteran population. Pacing Clin Electrophysiol. 2018;41(3):284-9. https://doi.org/10.1111/pace.13285.

217. Argamany JR, Lee GC, Duhon BD, Zeidan AR, Young EH, Reveles KR. A possible association between statin use and improved Clostridioides difficile infection mortality in veterans. PLoS One. 2019;14(5):e0217423. https://doi.org/10.1371/ journal.pone.0217423.

218. Li B, Mahmood A, Lu D, Wu H, Xiong Y, Qu C, et al. Simvastatin attenuates microglial cells and astrocyte activation and decreases interleukin-1beta level after traumatic brain injury. Neurosurgery. 2009;65(1):179-86. https://doi.org/10.1227/01.NEU.0000346272. 76537.DC

219. Vollmer T, Key L, Durkalski V, Tyor W, Corboy J, MarkovicPlese $\mathrm{S}$, et al. Oral simvastatin treatment in relapsing-remitting multiple sclerosis. Lancet. 2004;363(9421):1607-8. https://doi. org/10.1016/S0140-6736(04)16205-3.

220. Charoenngam N, Holick MF. Immunologic effects of vitamin D on human health and disease. Nutrients. 2020;12(7):8413. https://doi.org/10.3390/nu12072097.

221. Hewison M. Vitamin D and the immune system: new perspectives on an old theme. Endocrinol Metab Clin North Am. 2010;39(2):36579. https://doi.org/10.1016/j.ecl.2010.02.010.

222. Meltzer DO, Best TJ, Zhang H, Vokes T, Arora V, Solway J. Association of vitamin D status and other clinical characteristics with COVID-19 test results. JAMA Netw Open. 2020;3(9):e2019722. https://doi.org/10.1001/jamanetworkopen.2020.19722.

223. Singh S, Kaur R, Singh RK. Revisiting the role of vitamin D levels in the prevention of COVID-19 infection and mortality in European countries post infections peak. Aging Clin Exp Res. 2020;32(8):1609-12. https://doi.org/10.1007/s40520-020-01619-8.

224. Ye K, Tang F, Liao X, Shaw BA, Deng M, Huang G, et al. Does serum vitamin D level affect COVID-19 infection and its severity?-a case-control study. J Am Coll Nutr. 2020. https://doi. org/10.1080/07315724.2020.1826005.

225. Baktash V, Hosack T, Patel N, Shah S, Kandiah P, Van Den Abbeele $\mathrm{K}$, et al. Vitamin D status and outcomes for hospitalised older patients with COVID-19. Postgrad Med J. 2020;97(1149):442447. https://doi.org/10.1136/postgradmedj-2020-138712.

226. Hernández JL, Nan D, Fernandez-Ayala M, García-Unzueta M, Hernández-Hernández MA, López-Hoyos M, et al. Vitamin D status in hospitalized patients with SARS-CoV-2 infection. J Clin Endocrinol Metab. 2020. https://doi.org/10.1210/clinem/dgaa733.

227. Benskin L. A basic review of the preliminary evidence that COVID-19 risk and severity is increased in vitamin D deficiency. Front Publ Health. 2020;8(513):45. https://doi.org/10. 3389/fpubh.2020.00513.

228. Pugach IZ, Pugach S. Strong correlation between prevalence of severe vitamin D deficiency and population mortality rate from COVID-19 in Europe. medRxiv. 2020:2020.06.24.20138644. https://doi.org/10.1101/2020.06.24.20138644.

229. Rhodes JM, Subramanian S, Laird E, Kenny RA. Editorial: low population mortality from COVID-19 in countries south of latitude 35 degrees North supports vitamin D as a factor determining severity. Aliment Pharmacol Ther. 2020;51(12):1434-7. https://doi.org/10.1111/apt.15777.

230. Macaya F, Espejo Paeres C, Valls A, Fernández-Ortiz A, González Del Castillo J, Martín-Sánchez FJ, et al. Interaction between age and vitamin D deficiency in severe COVID-19 infection. Nutr Hosp. 2020;37(5):1039-42. https://doi.org/10.20960/nh.03193.

231. Postolache TT, Benros ME, Brenner LA. Targetable biological mechanisms implicated in emergent psychiatric conditions associated with SARS-CoV-2 infection. JAMA Psychiat. 2020;78(4):353354. https://doi.org/10.1001/jamapsychiatry.2020.2795. 
232. Yang AC, Kern F, Losada PM, Agam MR, Maat CA, Schmartz GP, et al. Dysregulation of brain and choroid plexus cell types in severe COVID-19. Nature. 2021;595:565-571. https://doi.org/ 10.1038/s41586-021-03710-0.
Publisher's Note Springer Nature remains neutral with regard to jurisdictional claims in published maps and institutional affiliations.

\section{Authors and Affiliations}

\section{Boris N. Tizenberg ${ }^{1} \cdot$ Lisa A. Brenner ${ }^{2,3,4,5}$. Christopher A. Lowry ${ }^{2,3,5,6,7,8}$. Olaoluwa O. Okusaga 9,10 .}

David R. Benavides ${ }^{11} \cdot$ Andrew J. Hoisington ${ }^{2,3,5,12} \cdot$ Michael E. Benros $^{13,14} \cdot$ John W. Stiller ${ }^{1,15,16} \cdot$ Ronald C. Kessler $^{17}$. Teodor T. Postolache ${ }^{1,2,5,18}$

1 Mood and Anxiety Program, Department of Psychiatry, University of Maryland School of Medicine, $685 \mathrm{~W}$. Baltimore Street, Suite\# 930, Baltimore, MD, USA

2 VA Rocky Mountain Mental Illness Research Education and Clinical Center (MIRECC), Rocky Mountain Regional Veterans Affairs (VA) Medical Center (RMRVAMC), Aurora, CO, USA

3 Department of Physical Medicine and Rehabilitation, University of Colorado Anschutz Medical Campus, Aurora, CO, USA

4 Department of Psychiatry and Neurology, University of Colorado Anschutz Medical Campus, Aurora, CO, USA

5 Military and Veteran Microbiome: Consortium for Research and Education, Aurora, CO, USA

6 Department of Integrative Physiology, University of Colorado Boulder, Boulder, CO, USA

7 Center for Neuroscience, University of Colorado Boulder, Boulder, CO, USA

8 Center for Neuroscience, University of Colorado Anschutz Medical Campus, Aurora, CO, USA

9 Menninger Department of Psychiatry and Behavioral Sciences, Baylor College of Medicine, Houston, TX, USA

10 Michael E DeBakey VA Medical Center, Houston, TX, USA
11 Department of Neurology, University of Maryland School of Medicine, Baltimore, MD, USA

12 Department of Systems Engineering and Management, Air Force Institute of Technology, Wright-Patterson Air Force Base, OH, USA

13 Biological and Precision Psychiatry, Copenhagen Research Centre for Mental Health, Mental Health Centre Copenhagen, Copenhagen University Hospital, Copenhagen, Denmark

14 Department of Immunology and Microbiology, Faculty of Health and Medical Sciences, University of Copenhagen, Copenhagen, Denmark

15 Saint Elizabeths Hospital-DBH Psychiatry Residency Training Program, Washington, DC, USA

16 Maryland State Athletic Commission, Baltimore, MD, USA

17 Department of Health Care Policy Harvard Medical School, Boston, MA, USA

18 Veterans Integrated Service Network (VISN) 5, VA Capitol Health Care Network, Baltimore, MD, USA 